\title{
CRIAÇÃO DO CAPITAL SOCIAL: \\ O CASO ASMARE - ASSOCIAÇÃO DOS CATADORES DE PAPEL, PAPELÃO E MATERIAL REAPROVEITÁVEL DE BELO HORIZONTE
}

\author{
Pedro Jacobi \\ Marco Antônio C. Teixeira
}




\section{Os Autores}

\section{Pedro Jacobi}

Doutor em Sociologia e Livre Docente em Educação pela Universidade de São Paulo. Professor Associado da Faculdade de Educação e do Programa de Pós-Graduação em Ciência Ambiental da Universidade de São Paulo.

\section{Marco Antônio C. Teixeira}

Doutorando em Ciência Política na PUC/SP. Professor da Fundação Santo André e pesquisador do Programa Gestão Pública e Cidadania desde 2001. 


\section{ÍNDICE}

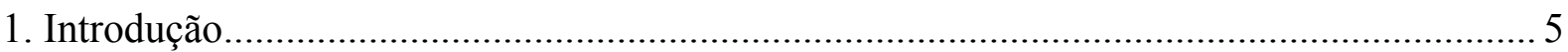

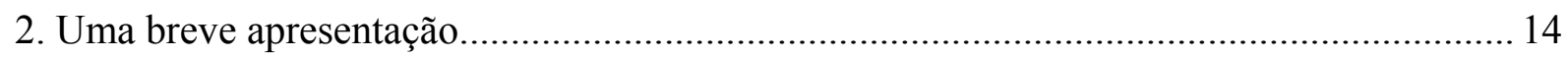

3. Um resgate histórico da mobilização e da organização dos catadores de papel: a importância dos atores sociais, os parceiros e as situações de conflitos

4. Da repressão à parceria: os caminhos do poder público .................................................... 18

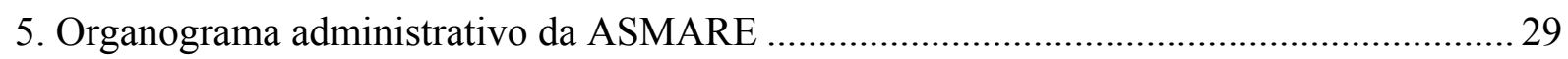

6. A ASMARE na voz dos catadores e do poder público .................................................. 40 


\section{Introdução}

Os moradores de rua sempre foram estigmatizados de vadios, vagabundos, malandros, preguiçosos, maltrapilhos, coitados e tantos outros adjetivos que constantemente os coloca na condição de não-cidadãos, na condição de o outro humano, ou de algo bem diferente de um ser humano comum. Viver na rua há muito tempo tem sido uma forma de se autoexcluir da sociedade. O morar na rua não estava associado como resultado da crise social, e muito menos como conseqüência do desemprego, fato social cada vez mais presente na sociedade contemporânea.

Morar na rua até pouco tempo atrás era visto principalmente como uma manifestação de natureza individual caracterizada pela existência de mendigos, de pessoas que romperam com os seus laços familiares e também daquelas que por algum distúrbio mental perderam o seu vinculo com grupo social com o qual conviviam. E na rua que sobrevivem, mantendo-se basicamente do que esta lhes dá; pode ser um prato de sopa para minimizar a fome, um cobertor para aquecer as madrugadas frias ou, até mesmo, uma garrafa de cachaça para esquecer o passado e um trocadinho para comprar uma "carteira de cigarro".

Nos dias de hoje é comum verificarmos a presença de um grande número de pessoas vivendo na rua e desta retirando sua condição de sobrevivência, tanto a individual quanto a familiar. Entre essas pessoas estão os sucateiros que recolhem ferro-velho e os catadores de papel e de materiais recicláveis que puxam seus carrinhos de madeira à procura de material reciclável para vender.

Muitos deles trabalhavam no mercado formal e com a crise do desemprego se viram obrigados a optar por essa forma de sobrevivência. Este é um dos novos elementos que compõe a população de rua e que se mistura aos mendigos e a tantos outros andarilhos que se desgarraram do meio social e familiar e encontraram na rua algum sentido para poder manter as suas vidas.

Os censos demográficos, por privilegiarem os moradores em domicílios, não dizem quantos são e nem fazem qualquer menção sobre a existência da População de Rua. Porém, esta existe e tem representado um grande desafio para o poder público, principalmente no nível da gestão local.

Os que antes eram caracterizados como mendigos, pedintes e até mesmo desequilibrados mentais que perderam seus laços familiares, ganhou nova conotação ao se observar na 
População de Rua a presença de famílias inteiras que passaram a desenvolver alguma atividade econômica relacionada com o que a rua pode lhes oferecer.

A nova realidade da População de Rua, principalmente nas grandes cidades brasileiras, tem apontado para a necessidade de se estabelecer iniciativas diferenciadas das que tradicionalmente eram, ou ainda vem sendo, tomadas pelo Poder Público. A tônica, obrigatoriamente, tem que enfatizar uma alternativa ao campo assistencial.

Para além de mendigos, pedintes ou de pessoas que se deserdaram do meio social, a população de rua, hoje, é composta principalmente daqueles que foram excluídos do mercado de trabalho e afetados por uma situação de miséria absoluta que tem afligido uma parte considerável de cidadãos; provocando a desintegração familiar, a ruptura social e retirando por completo a auto-estima dessas pessoas.

Notando que em Belo Horizonte a População de Rua possui todas essas características, se misturando mendigos com trabalhadores e muitas vezes famílias inteiras vivendo na rua, ou da rua, um grupo de pessoas vinculadas á Pastoral de Rua e aos movimentos sociais realizou em 1989 uma pesquisa ${ }^{1}$ para identificar quem é essa população e como tem sobrevivido, além de buscar saber, também, quais as suas principais queixas em relação aos moradores e administradores da cidade.

Antes de se saber o resultado da pesquisa, os próprios envolvidos já notavam que a existência desse grupo social provocava diversas reações, tanto por parte dos administradores municipais, como pelos moradores da cidade.

Da parte do Poder Público, quando não há uma compreensão adequada da origem do problema em questão, o que se nota são geralmente iniciativas repressivas visando retirálos de circulação sob o argumento da necessidade de se manter uma "aparente limpeza" das ruas da cidade e também, preservar "a segurança das pessoas". Aqui entende-se por pessoas aqueles circulam nas ruas para fazer suas compras e os que moram nas imediações onde se concentram os moradores de rua.

Por parte da população, quando esta não está adequadamente informada sobre as razões da existência dos moradores de rua, o que se nota é uma reação que de certa forma acompanha o argumento utilizado pelo Poder Público, atribuindo à População de Rua toda a responsabilidade pela sujeira e pela má conservação das vias públicas, assim como

1 Esta pesquisa foi realizada em 1989 pelo Departamento de Serviço Social da PUC-MG onde posteriormente se cadastrou cerca de 600 catadores de papel que sobrevivem trabalhando no centro da cidade. Ver Rosa, M., M., Cleisa, (organiz.), in "População de Rua: Brasil e Canadá", Editora Hucitec, São Paulo, 1995. 
também do temor de assaltos. Existe em relação a ela um comportamento preconceituoso quase sempre justificado pela aparência e pela condição na qual se encontram, e quase sempre acusados de serem drogados, alcoólatras ou marginais.

Quando se trata da População de Rua, o olhar de uma grande parcela da sociedade é sempre acusador, olhar este que expulsa essa população do meio e da convivência social, reforçando a situação de apartheid social existente. Esse olhar repele a presença dessas pessoas na rua sempre sob o argumento de que estão se apropriando de um espaço público que não lhes pertence, ou que não estão adequadamente educadas para se utilizar desse espaço. Para uma parte da sociedade, a População de Rua é vista como uma ameaça ao equilíbrio do seu cotidiano.

Essas são algumas das reclamações da população de rua, apesar de comum a todas as cidades, verificadas na pesquisa realizada em 1989 com o objetivo de traçar um perfil dos moradores de rua em Belo Horizonte. Nesta mesma pesquisa verificou-se que $77 \%$ dessas pessoas vivem há mais de doze anos na cidade, 48\% vieram do interior do Estado de Minas Gerais e que na sua grande maioria estavam na idade produtiva, entre 21 e 44 anos.

O período de realização da pesquisa abrange os constantes conflitos havidos entre o Poder Público e a População de Rua que sobrevive da coleta de materiais recicláveis presentes no lixo depositado pelo comércio na região central da cidade. Esse também é o período embrionário da ASMARE - Associação dos Catadores de Papeis, Papelão e Materiais Recicláveis fundada oficialmente em $1^{\circ}$ de maio de 1990 por "catadores de papel" da região central da cidade com auxílio da Pastoral de Rua e de alguns movimentos sociais.

No período entre 1990 e 1992 ocorrem alguns conflitos entre catadores de papel e Poder Público, assim como se consolidam algumas conquistas por essa população: 1) a garantia de prioridade na coleta seletiva conforme está previsto na Lei Orgânica Municipal; 2) a conquista de um galpão num terreno ocupado pelos catadores em 1990 e o reconhecimento por parte do Poder Público, em função da mobilização dos catadores, da importância do seu trabalho, notadamente a partir da iniciativa de construção do galpão.

As eleições para a Prefeitura da cidade realizadas em novembro de 992 foram vencidas pela "Frente BH Popular", integrada por várias pessoas que acompanharam e apoiaram a trajetória de luta dos catadores de papel.

Ao tomar posse em 1993, o grupo que assumiu a direção da Superintendência de Limpeza Urbana da Cidade e da Secretaria Municipal de Desenvolvimento Social realizou uma 
nova pesquisa2 com essa população. $\mathrm{O}$ objetivo foi de traçar um perfil atualizado e formular as propostas que as incluíssem oficialmente no sistema de limpeza urbana da cidade aproveitando a sua experiência de trabalho na separação e venda de materiais recicláveis.

Os resultados dessa pesquisa apontaram para um quadro bastante complexo. De todos os entrevistados a predominância é masculina com $82 \%$, enquanto as mulheres representam $18 \%$. Quanto à escolaridade, $22 \%$ são analfabetos, $57 \%$ cursaram até a 4 serie do primeiro grau; $17 \%$ concluíram o primeiro grau; $3 \%$ concluíram o segundo grau e uma catadora de papel respondeu ter concluído um curso superior.

O dado surpreendente da pesquisa é que a maioria dessas pessoas, apesar de viverem na rua e muitas vezes dormirem no próprio local de trabalho para garantir a segurança do material recolhido, possuem imóvel próprio onde residem com a sua própria família. As respostas apontaram para 56\% com imóvel próprio; 13\% morando em residências alugadas; $5 \%$ morando de favor em casa de parentes ou amigos; $24 \%$ morando na rua e $2 \%$ residindo em ocupações clandestinas ou em pensionatos.

Neste quadro que revela que $76 \%$ possuem algum tipo de residência fixa, observa-se também uma sensível desagregação da unidade familiar. Quando perguntados se retornam para suas casas ao final de cada dia de trabalho; $47 \%$ disseram que sim; $6 \%$ responderam que vão para casa a cada dois dias; $22 \%$ disseram que só retornam para casa nos finais de semana e $1 \%$ não souberam precisar quando retornam às suas residências. O percentual de pessoas que se dizem Moradoras de Rua se manteve em 24\%.

O motivo de dormir nas ruas está relacionado não só com a manutenção do material recolhido, como também pelo fato de poder estar coletando mais recicláveis e aumentando a renda com a venda do produto.

A pesquisa apontou também que alguns catadores já tinham desenvolvido um certo grau de relacionamento com a população da cidade. Isto é confirmado quando 19\% dos entrevistados dizem já receber o material que recolhem de forma seletiva cuja separação é feita por comerciantes e moradores de residências particulares. 
A maior dificuldade, apontada como sendo prejudicial ao desenvolvimento do trabalho, está no fato de não existir um local fixo para o armazenamento e triagem adequada dos materiais recolhidos. Quando perguntados sobre essa questão, 28\% responderam que armazenam o material na própria rua onde o recolhem; 64\% não o armazena, o que indica que vendem imediatamente o que recolhem não obtendo, portanto, um bom preço pela mercadoria, Outros 6\% dizem armazenar o material na Associação. Nessa época só existia o galpão da avenida Contorno -; $1 \%$ não soube responder e $1 \%$ leva o material para suas casas.

Com os resultados desta pesquisa em mãos, o Poder Público já dispunha de várias informações fundamentais para a elaboração de uma parceria com a ASMARE e com a Pastoral de Rua. Esta parceria se converteu numa experiência cujo sucesso tem repercutido e provocado uma sensível melhoria na qualidade de vida dos catadores da cidade, possibilitando uma mudança no relacionamento com a população e tornando-se um ator social exemplar em iniciativas que contribuem para ampliar a justiça social.

O resgate histórico desta experiência e o importante papel desempenhado pela Pastoral de Rua, além da vontade política transformada em iniciativas concretas pelo Poder Público para o resgate da cidadania dessa população, são os principais fatores que destacamos neste relatório, onde a consolidação da ASMARE - Associação dos Catadores de Papel, Papelão e Materiais Reaproveitáveis, é o ponto central desta experiência bem sucedida.

É importante lembrar que a experiência da ASMARE é fruto da luta de vários atores sociais que caminham juntos desde o tempo das famosas "operações-limpeza". Três atores são absolutamente fundamentais e, portanto, serão privilegiados nesse relatório.

Trata-se de: 1) os Catadores de Papel que acreditaram, mesmo nos momentos mais adversos, que poderiam de forma organizada serem reconhecidos enquanto cidadãos; 2) a Pastoral de Rua que se notabilizou pela persistência em contribuir com a organização dos catadores e ampliar o leque de solidariedade nos períodos mais difíceis e, 3) o Poder Público que mesmo correndo o risco de ser incompreendido pela população da cidade assumiu, a partir de 1993, o papel de indutor das condições estruturais necessárias para que a iniciativa tenha, não só, uma sólida existência, como possa atingir um maior grau de autonomia. 


\section{Contextualização Sócio-ambiental da cidade}

Belo Horizonte localiza-se no Estado de Minas Gerais na Região Sudeste do país. Foi fundada no ano de 1897 como um município planejado para sediar a capital do Estado. A sua população é de 2.020.161 habitantes, das quais 99,66\% residem no perímetro urbano ${ }^{3}$. Esses habitantes se distribuem numa área total de $335 \mathrm{Km}^{2}$ representando uma densidade demográfica de 6.030.33 habitantes por $\mathrm{Km}^{2}$. Registra-se ainda na cidade, a existência de 139 favelas. A renda média da população está em torno de US\$481,00. As principais atividades econômicas são desenvolvidas pelos setores de comércio e de serviços, sendo que as industrias se concentram na Região Metropolitana ${ }^{4}$.

A Região Metropolitana de Belo Horizonte abrange 14 municípios com uma população total de 3.703.835 habitantes ${ }^{5}$. Com exceção das cidades de Betim e de Contagem; onde se concentram os distritos industriais - com destaque para a indústria automobilística e de siderurgia - os demais municípios são considerados "cidades dormitórios", já que uma parte considerável de seus moradores desenvolve suas atividades profissionais em Belo Horizonte, fazendo pouco uso dos serviços públicos locais das cidades em que residem.

Existem em Belo Horizonte 502.147 domicílios urbanos e rurais. Destes, 94,3\% possuem ligação de água potável adequadamente dentro de suas casas. Em relação à ligação com a rede de esgotos, o percentual de domicílios que se beneficia com este tipo de serviço é de $86,4 \%$.

São produzidos nos domić́lios da cidade - particulares e comerciais - cerca de 4200 toneladas/dia de resíduos sólidos. Destes, 65\% são formados por matéria orgânica, 27\% por materiais recicláveis e $8 \%$ por rejeitos que não podem mais ter nenhum tipo de reutilização.

Quanto aos serviços de coleta de lixo domiciliar, é de se destacar o significativo avanço ocorrido entre os anos de 1993 e 1996. No ano de 1993 apenas 65\% dos moradores da cidade eram atendidos com a coleta de lixo em suas residências. No final do ano de 1996, o número de domicílios beneficiados regularmente com a coleta de lixo atingiu o índice de $95 \%{ }^{6}$.

3 Ver censo demográfico de 1991, IBGE.

4 Ver a publicação institucional "Modelo de Gestão dos Resíduos Sólidos" sob responsabilidade da Assessoria de Comunicação Social da

Superintendência de Limpeza Urbana de Belo Horizonte.

5 Ver censo demográfico de 1991, IBGE.

6 Informação concedida pela SLU ao pesquisador do CEDEC em maio de 1997. 


\section{Os problemas sociais e a emergência dos catadores de papel}

Como na maioria das cidades de médio e de grande porte do Brasil, o município de Belo Horizonte tem vivido uma grave crise social ocasionada, principalmente, pela queda na oferta de empregos e pela redução no número de postos de trabalho existentes. Isso impacta de forma mais dramática os setores mais carentes da população representados pelos não escolarizados e ausentes de formação profissional adequada para os dias de hoje.

O impacto do desemprego em Belo Horizonte, em fevereiro de 1997, afetou 7,3\% da população economicamente ativa - PEA ${ }^{7}$. Em Outubro de 1996 essa mesma taxa foi de $6,5 \%$ enquanto no mês de dezembro o percentual de pessoas que estavam a procura de um emprego era de $6,0 \%$ da $\mathrm{PEA}^{8}$.

O problema do desemprego tem sido a principal causa do aumento no número de pessoas que passaram a viver nas ruas. Historicamente, sempre houve a presença de pessoas que retiram das ruas a sua condição de sobrevivência, essas pessoas eram conhecidas por sua atividade econômica e não tinham semelhança com o que se caracteriza como População de Rua nos dias de hoje.

Em Belo Horizonte, no início dos anos 80, houve um crescimento significativo da presença de População de Rua devido ao agravamento da crise social em decorrência diminuição da oferta de empregos. A população em questão passou a buscar as mais variadas formas de trabalho para poder garantir a sua sobrevivência.

No caso mais especifico dos catadores de papel, função já tradicional na cidade que era exercida por um pequeno grupo, observa-se que na região central da cidade ocorre um aumento das pessoas que passaram a recolher materiais reaproveitáveis. Nesse momento trabalhar com o recolhimento de papéis, vidro e metais, não era mais só uma opção individual de algumas pessoas que exerciam a função; pessoas muitas vezes autodenominadas de sucateiros e vendedores de ferro-velho. O desempenho dessa atividade se transformou numa questão de garantia mínima sobrevivência em condições de trabalho absolutamente adversas.

O que se vê neste período é um aumento do número de catadores puxando carrinhos de madeira e retirando papéis e papelão colocados no lixo das calçadas. A presença dos catadores ganha visibilidade mais pelo seu aspecto negativo - remexendo no lixo alheio e

7 Ver boletim “Pesquisa de Emprego e Desemprego", pág. 3, ano 3, n 2, fevereiro de 1997, Fundação João Pinheiro, Secretaria de Planejamento do Governo do Estado de Minas Gerais.

8 Ídem ao 7. 
muitas vezes deixando-o espalhado pelo chão, do que pela sua contribuição com a limpeza urbana - pelo fato de não terem outra forma de sobrevivência, que não aquela.

O aumento da exclusão de mão de obra tem gerado graves problemas sociais, e desafiado principalmente as administrações no nível local. São as prefeituras que sentem o impacto mais imediato dos problemas relacionados com a precariedade nas condições de moradia e com o aumento de pessoas que passam a viver de atividades que constituem um mercado de trabalho marginal.

A não equação deste problema tem contribuído para a multiplicação dos "não-cidadãos"; pessoas que por não verem nenhuma outra alternativa de sobrevivência, acabam caindo num nomadismo urbano em busca de ganhar a vida perambulando pelas praças e ruas das cidades, a espera de algo que a cidade possa oferecer-lhes. No caso dos catadores sua função, apesar de definida e de encontrar espaço num mercado econômico, era reprimida pelo próprio Poder Público.

Em Belo Horizonte esse exército de nômades urbanos foi alvo de todos os tipos de preconceito, principalmente dos setores mais conservadores. Os catadores de papel, num período prévio ao de sua organização, tiveram muitas dificuldades em se mostrar enquanto trabalhadores que desempenhavam um papel socialmente importante para a cidade.

O poder público à época foi o principal estimulador dessa imagem negativa, pois ao ser cobrado pela população sobre a manutenção e limpeza das ruas centrais da cidade atribuía aos catadores a responsabilidade pela situação aplicando mecanismos repressivos como forma de impedir o trabalho dos catadores.

Enfrentando um poder público que por muitas vezes criou dificuldades e uma sociedade conservadora que relutava em assimilar o fato dos catadores desenvolverem seu trabalho nas ruas, estes se somaram aos seus parceiros catadores - comunidades de igreja ambientalista e diversos setores da sociedade civil -, e conjuntamente criaram a ASMARE - Associação dos Catadores de Papel, Papelão e Materiais Reaproveitáveis de Belo Horizonte - em $1^{\circ}$ de maio de 1990.

Juntos passaram a enfrentar os principais desafios colocados por uma sociedade que resistia a idéia de ver os catadores de papel desempenhando as suas atividades como qualquer outro tipo de profissional. Um fato a destacar é motivação a mobilização para elaborar uma política pública de coleta seletiva do lixo que incorporasse a experiência e o importante trabalho que estava sendo desenvolvido pelos catadores. 
A mobilização ocorreu pelo fato do prefeito à época, - o hoje Governador Eduardo Azeredo - por força de dispositivo presente na elaboração da Lei Orgânica Municipal, formular um projeto de implementação de uma política de coleta seletiva. Neste projeto previa-se que a coleta seria gerenciada pelo setor privado.

A implementação de uma política pública de coleta seletiva era bem vinda e considerada necessária por todos os atores sociais envolvidos no processo de organização da ASMARE. Já o gerenciamento pelo setor privado poderia colocar em risco o trabalho dos catadores, porque não se teria qualquer garantia de que os catadores poderiam ter um espaço privilegiado para retirar e comercializar o material reciclável. O argumento era o de que numa situação de concorrência em igualdade de condições com o setor privado, este teria condições econômicas para suplantar o trabalho dos catadores, colocando em risco a existência da própria Asmare.

Tal mobilização viabilizou em 06 de setembro de 1991, por ocasião da votação da Lei Orgânica, a inclusão de instrumentos que criaram outras condições para o gerenciamento da Coleta Seletiva ${ }^{9}$. Estes instrumentos garantiram aos catadores, o papel de "parceiros privilegiados" na elaboração e no gerenciamento de políticas de coleta seletiva e reciclagem do lixo na cidade de Belo Horizonte. Isto representou o primeiro passo para a profissionalização e o reconhecimento público do trabalho que há muito tempo já vinha sendo desenvolvido pelos catadores.

O maior salto de qualidade ocorreu ao final do ano de 1992 por ocasião da posse de uma nova gestão frente à prefeitura de Belo Horizonte. A nova equipe composta por pessoas que sempre se solidarizaram com a luta pela valorização do trabalho dos catadores, foi responsável pela elaboração de um convênio entre catadores, Mitra Arquidiocesana ${ }^{10}$ e a Prefeitura da cidade.

Através de convênio firmado entre as partes, coube ao Poder Público repassar os recursos necessários para consolidar a instituição e possibilitar a sua expansão. O número de associados que era de 31 em 1993, chegou a 210 no inicio de 1997. Aumenta também o número médio da produção de recicláveis que era de pouco mais de 30 toneladas por mês durante ano de 1994, para mais de 242 toneladas recolhidas no mês de janeiro de $1997^{11}$.

9 O capítulo 3 em seu artigo 151 diz que "a coleta seletiva será realizada preferencialmente por cooperativas de trabalhadores.

10 A Mitra Arquidiocesana representa a Pastoral de Rua. É a figura jurídica da Arquidiocese de Belo Horizonte.

11 Ver relatório de atividades da ASMARE publicado em abril de 1997. 
Cabe destacar o papel da Pastoral de Rua no processo de aglutinação dos catadores e no amadurecimento de um projeto que se desdobra na fundação da ASMARE. Porém o ponto central a ser destacado é sobre o papel exercido pelo Poder Público enquanto estimulador e indutor de condições favoráveis para obtenção do capital social.

\section{Uma breve apresentação}

Criada oficialmente em primeiro de maio de 1990, a ASMARE - Associação dos Catadores de Papel, Papelão e Material Reaproveitável de Belo Horizonte, representa uma articulação entre a população que vive da separação de materiais recicláveis do lixo domiciliar e comercial, a Pastoral de Rua da Igreja Católica - que trabalha preferencialmente com a população que retira das ruas sua condição de sobrevivência -, com a Administração Municipal que veio a ter uma preocupação explícita em dar respostas a essa problemática social a partir do ano de 1993.

A história da ASMARE tem um antecedente de lutas que aglutinaram diversos atores sociais. Num primeiro momento foi a Pastoral de Rua quem se encarregou de organizar os catadores de papel que viviam dispersos pela cidade. Estes, até então, estavam sujeitos a um tratamento de acordo com a vontade política de quem estivesse à frente da Prefeitura do município.

Foi a Pastoral quem chamou a atenção da Sociedade Civil organizada para a problemática vivida pelos catadores de papel, articulando a solidariedade externa e fortalecendo um tecido social interno que se consolida substancialmente na medida em que as parcerias de trabalho se efetivam e ganham visibilidade pública.

Somam-se em parceria ao trabalho desenvolvido pela Pastoral diversas entidades ambientalistas e de direitos humanos. Juntas, buscaram sensibilizar a sociedade local para as más condições nas quais os catadores de papel desenvolviam o seu trabalho. Desse conjunto de parceiros da história de luta dos catadores, alguns assumiram responsabilidades frente a nova gestão municipal, entre eles o prefeito eleito Patrus Ananias e a presidenta da AMDA - Associação Mineira de Defesa do Meio Ambiente Heliana Kátia Tavares.

A presença na nova gestão de pessoas com uma visão voltada para a valorização do trabalho dos catadores fez com que a Prefeitura de Belo Horizonte realizasse através de um convênio, o repasse de recursos financeiros e humanos que viabilizam o funcionamento da 
entidade e contribuem para o seu amadurecimento. Isto foi fundamental para a consolidação de um trabalho que se volta para o resgate da dignidade e da cidadania dessa população até então sempre marginalizada pela Administração Municipal.

É importante ressaltar que o encontro entre Poder Público, Igreja e a População de Rua, foi o resultado de lutas conjuntas centradas no direito a cidadania da população excluída. Este contato iniciou-se na convergência de valores humanitários traduzidos no combate às políticas discriminatórias praticadas pelas gestões municipais anteriores. Estas políticas ao excluir a população em questão deste tipo de atividade econômica, as colocavam na condição de "marginais" aos olhos dos moradores da cidade. Isto ocorria principalmente, quando a própria prefeitura procurava responsabilizar os catadores pela sujeira e pela falta de manutenção das ruas da região central da cidade.

O resgate histórico a seguir visa dar conta desse momento, no intuito de demonstrar que a convergência de valores fundados no respeito aos direitos humanos e à dignidade das pessoas pode resultar em iniciativas de extrema relevância quanto ao seu conteúdo social, e que podem servir de modelo para o enfrentamento de problemas cuja origem ocorra em situações similares.

Outro fator a destacar está na escolha de pessoas que à frente de uma Administração Municipal viabilizam projetos centrados no fortalecimento da inclusão social. Isto tem sido fundamental para o surgimento de iniciativas públicas que em muito vem contribuindo para a melhoria da qualidade de vida das populações mais carentes e para a conseqüente recuperação da auto-estima pessoal e da valorização do trabalho comunitário.

\section{Um resgate histórico da mobilização e da organização dos Catadores de Papel: a importância dos atores sociais, os parceiros e as situações de conflitos}

Em 1987 chega a Belo Horizonte um grupo de irmãs beneditinas trazendo consigo o acúmulo da experiência de um trabalho desenvolvido junto a população de rua no município de São Paulo. A experiência em questão, ocorreu através de iniciativas com os catadores de papel que no início do ano de 1989 resulta na criação da Coopamare Cooperativa de Catadores de Papel Autônomos na capital paulista e, que tem contribuído de maneira bastante significativa para o resgate da cidadania e para a melhoria das condições de vida dos catadores envolvidos na iniciativa. 
A chegada desse grupo de religiosas marcou também o período em que a Igreja Católica local começou a desenvolver os primeiros contatos com a população que mora ou retira sua sobrevivência nas ruas de Belo Horizonte. As características encontradas demonstraram muitas similaridades entre o que ocorreu durante a experiência desenvolvida em São Paulo. A carência absoluta da população se traduzia na rejeição de qualquer contato externo, reagindo de forma agressiva e arredia à aproximação de terceiros o que de inicio criou uma certa dificuldade no processo de organização.

Os catadores reagiam desta forma por já estarem acostumados à repressão social desencadeada de um lado pelo Poder Público que os tratava como se fossem marginais, e de outro pela própria sociedade que simplesmente não queria reconhecer a sua existência na cidade, em virtude de sua aparência e seus trajes maltratados. A equipe da Pastoral percebeu que primeiro era preciso ganhar a confiança dessa população para poder organizá-la e capacitá-la a lutar por melhores condições de vida.

O primeiro contato se deu com as pessoas que se concentravam na região central da cidade, e isto foi suficiente para diagnosticar a existência de duas realidades distintas, o que colocou ao grupo da Pastoral a necessidade de uma reflexão sobre os objetivos do trabalho. A opção por um dos grupos significava métodos diferenciados de ação.

A primeira realidade referia-se à população que estava nas ruas por depender da catação de materiais recicláveis para prover renda para o sustento de suas famílias. A segunda, referia-se à existência de mendigos que tiravam sua sobrevivência daquilo que a cidade lhes dava.

No primeiro caso, a relação se daria com uma população de trabalhadores marginalizados socialmente e que tinham algum tipo de engajamento numa atividade econômica, mesmo que marginalizada. Na relação com os mendigos, o trabalho teria de ser de natureza assistencial, já que esta população não desenvolvia nenhum tipo de atividade econômica e se encontrava numa situação de total dependência.

A opção de trabalho se deu em torno dos catadores de papel devido à possibilidade de empreender em médio prazo uma iniciativa que representaria o resgate da dignidade e da cidadania do grupo alvo. Viu-se que era necessário inverter a relação destes com a sociedade. O objetivo era de inseri-los enquanto trabalhadores que contribuem com a limpeza da cidade, e que sobrevive de uma atividade econômica que precisa ser valorizada por todo o conjunto da sociedade. 
Segundo os membros da Pastoral, para se alcançar esse objetivo foi necessário politizar a relação do catador de papel com a cidade, transformando uma visão já existente, e que estava estereotipada no sentido dos catadores serem vistos como pessoas que contribuem para a sujeira na cidade". Mudar esse estereótipo significava também resgatar a autoestima dos catadores enquanto cidadãos e torná-los conscientes de que desenvolvem um trabalho que traz benefícios não só para si, mas para toda a comunidade.

Para tanto era necessário mostrar que os catadores, ao contrário do que se imagina, contribuem "para a limpeza e manutenção do meio ambiente local". Logo os membros da Pastoral perceberam que esse fato só se daria através da somatória de esforços envolvendo o Poder Público notadamente a Prefeitura que tem sob sua jurisdição a responsabilidade das políticas de limpeza urbana -, a Sociedade Civil - que poderia estar contribuindo na elaboração de parcerias e ampliando o leque de solidariedade -, e os próprios catadores que estariam abertos a assimilar os novos hábitos a partir do interesse coletivo e da conscientização de seu papel enquanto ator social em busca de uma nova identidade.

A realidade encontrada em Belo Horizonte apontou para a possibilidade do desenvolvimento de um trabalho semelhante ao que se iniciara em São Paulo. As características sociais diagnosticadas eram semelhantes: famílias inteiras se dedicando á catação de papéis e papelão, muitas pessoas dormindo na rua para zelar pela segurança do produto recolhido devido à ausência de um galpão adequado para dispor o material; a ausência de quaisquer tipo de orientação quanto aos aspectos de higiene, aparência, segurança, relações sociais e saúde pessoal, fatos que causavam constrangimentos no contato entre os catadores de papel e a população em geral.

Outro fato comum a ambas experiências, no relato dos membros da Pastoral, é que os mecanismos de repressão desenvolvidos até então pela prefeitura da capital mineira, eram semelhantes aos que vinham sendo acionados pelo então prefeito Jânio Quadros (19861988) em São Paulo ${ }^{12}$.

Para atingir os objetivos propostos era necessário inicialmente que os catadores que até então atuavam de maneira muito dispersa se organizassem. Outra necessidade era a de desenvolver práticas educativas que permitissem a obtenção de noções mínimas de direitos, responsabilidades e também da sua importância enquanto trabalhadores.

12 Estes mecanismos eram denominados de "operação limpeza". Estas operações visavam culpar a atividade dos catadores pelo acúmulo de sujeira e pela proliferação de lixo nas ruas, passando uma idéia de que seriam removidos também junto com o lixo acumulado, os próprios catadores. 
As primeiras atividades que possibilitaram o contato entre os catadores ocorreram em torno de sopões e de chás comunitários, "onde havia catadores, a Pastoral se aproximava" relata José Aparecido Gonçalves, conhecido como Cido, responsável pela Coordenação da Equipe de Agentes Pastorais que trabalha com os catadores. Foi essa aproximação que permitiu aos catadores enfrentar de forma organizada os mecanismos repressivos até então acionados pelos órgãos públicos e mobilizar-se para exigir respeito e atenção dos órgãos do Estado que os reprimiam.

A mudança de uma situação onde os catadores estavam acostumados a apenas se defenderem dos constrangimentos a que eram submetidos, para a uma outra, onde reivindicam não só a exigência do direito de trabalharem livremente, como também a elaboração políticas e de iniciativas criando melhores condições de trabalho, representaram os frutos dos primeiros contatos entre a Pastoral e os catadores.

Os agentes pastorais passam a ser acionados sempre e quando os catadores eram de alguma forma constrangidos no seu cotidiano. A confiança necessária na relação entre Pastoral e catadores era mútua e já tinha se consolidado.

Foi numa dessas "Operações Limpeza”, desencadeadas pelo Poder Público que se tornou possível mostrar aos catadores que somente através de sua organização poderiam estar enfrentando os problemas e mudando a sua própria história. O resultado desse conflito representou um salto de qualidade na organização dessa população e colocou definitivamente os catadores de papel como atores sociais relevantes na cidade de Belo Horizonte.

\section{Da repressão à parceria: os caminhos do Poder Público}

As Operações Limpeza organizadas pela prefeitura sempre tiveram como objetivo retirar das ruas o lixo e também quem do lixo tirasse o seu sustento. Esse sempre foi um dos grandes dramas dos catadores de papel em Belo Horizonte e também em várias cidades brasileiras.

Foi num amanhecer, do dia 22 de agosto de $1988^{13}$, que cerca de 70 catadores da região central de Belo Horizonte sofreram mais um desses constrangimentos. A intenção da Operação Limpeza era a mesma de sempre, "limpar o lixo e remover os catadores para o mais longe possível". Informados dos acontecimentos, os membros da Pastoral que já

13 Período (1986-1988) corresponde ao exercício do mandato do Prefeito Sérgio Ferrara do PMDB 
tinham travado os primeiros contatos com os catadores, saíram em busca de notícias percorrendo a cidade toda para localizá-los.

Após percorrerem a cidade descendo as margens do Rio Arrudas, os membros da Pastoral de Rua localizaram os catadores na divisa de Belo Horizonte e Contagem, distante $15 \mathrm{Km}$ da região em que se encontravam. Estavam assustados e sem saber que iniciativas tomar. Nesse momento, o trabalho da Pastoral de Rua despontou como uma referência de confiança, e os catadores não mais tomavam quaisquer atitudes sem antes consultar os "amigos" da Pastoral.

Segundo José Aparecido, é a partir desse momento que se desencadeia um processo de reuniões na rua, estabelecendo laços sólidos de amizade entre a Pastoral e a População de Rua. A Igreja se posicionou de forma solidária iniciando um processo de mobilização pela defesa dos direitos dos catadores.

Essa aproximação decorre principalmente da forma violenta como o Poder Público tratava os catadores. Foi o primeiro passo que se desdobrou num trabalho de conscientização que resulta na criação da ASMARE em 1990.

Porém, até chegar 1990, novas Operações Limpeza são realizadas. Os catadores, que já se encontravam num processo bem amadurecido de organização, não mais foram vitimados pelo Poder Público, apesar de ainda sofrerem muitos preconceitos. O Poder Público apenas os tolerava, e não criava qualquer tipo estrutura que contribuísse para a melhoria das atividades dos catadores e garantisse o seu reconhecimento social.

As mobilizações e o fortalecimento da sua organização tornavam-se cada vez mais necessária. Discutia-se a elaboração da nova Lei Orgânica do Município, e o prefeito demonstrou interesse em fazer cumprir um dispositivo previsto na nova lei, iniciando a discussão de um projeto de implantação de coleta seletiva de lixo. Era intenção do prefeito transferir o gerenciamento da coleta seletiva para o setor privado.

$\mathrm{Na}$ avaliação dos membros da Pastoral e dos envolvidos com a mobilização, este lato poderia ser danoso para as atividades dos catadores. O setor privado ao assumir o controle da coleta seletiva disporia de mecanismos mais eficazes, assumindo o monopólio dos serviço, colocando os catadores à margem do seu trabalho.

Após muitos debates e da mobilização de diversos setores da sociedade, os catadores saíram em defesa de uma política de coleta seletiva articulada com as suas atividades. Se a 
reivindicação fosse vitoriosa garantir-se-ia o reconhecimento das atividades dos catadores enquanto profissionais. Após vários protestos em frente à Prefeitura e a Câmara Municipal, o prefeito recua na sua intenção inicial de articular a coleta seletiva com o setor privado e a questão foi colocada para discussão pública.

O recuo do prefeito e a continuidade do processo mobilizatório se desdobrou numa grande vitória para os catadores no final do ano de 1989. Conseguiram incluir na pauta de discussões e depois fazer aprovar na nova Lei Orgânica do Município, em seu Capítulo III - Do Saneamento Básico, no artigo 15 1, item VII, uma normativa que os coloca como atores privilegiados junto ao serviço de limpeza urbana da cidade. Nessa parte da Lei Orgânica atribui-se responsabilidades dentre as quais destaca-se que:

“ O Município manterá sistema de limpeza urbana, coleta, tratamento e destinação final do lixo observado o seguinte: I) a coleta de lixo será seletiva; II) o Poder Público estimulará o acondicionamento seletivo dos resíduos; III) os resíduos recicláveis serão acondicionados para a reintrodução no ciclo do sistema ecológico; IV) os resíduos não recicláveis serão acondicionados e terão destino final que minimize o impacto ambiental; V) o lixo séptico proveniente de hospitais, laboratórios e congêneres será acondicionado e apresentado à coleta em contenedores especiais, coletado em veículos próprios e específicos e transportado separadamente, tendo destino final em incinerador público; VI) os terrenos resultantes de aterros sanitários serão destinados a parques ou áreas verdes; VII) a coleta e a comercialização dos materiais recicláveis serão feitas preferencialmente por meio de cooperativas de trabalho" ${ }^{, 14}$.

A nova Lei Orgânica que entrou em vigor no ano de 1990, significou um reconhecimento institucional do trabalho dos catadores. E importante destacar que essa legitimação, traduzida nos dispositivos presentes na nova legislação, foi fruto do trabalho iniciado pela Pastoral de Moradia que conseguiu articular uma ampliação do leque de solidariedade aos catadores, assim como uma mobilização em torno do reconhecimento pelas atividades que estes desenvolvem.

O passo seguinte era o de conquistar o respeito da população e ampliar o grau de organização dos catadores. A ASMARE já era reconhecida publicamente e o seu papel ia se orientando cada vez mais na direção do resgate da auto-estima e da cidadania dos seus associados.

14 Ver Lei Orgânica do Município de Belo horizonte, 1990, páginas 48 e 49. 


\section{Os primeiros passos da ASMARE}

Apesar dos catadores se constituírem enquanto atores sociais reconhecidos após as várias mobilizações ocorridas, novos incidentes com o poder público continuava a acontecer Porém, a diferença observada era que o grau de solidariedade entre si era maior, assim como o processo de conscientização dos seus direitos lhes indicava as formas de melhor enfrentar as dificuldades encontradas. Agora não mais fugiam ou se escondiam da polícia, nem mesmo da perseguição desencadeada pelo Poder Público, aprendendo a se defender, reclamando e lutando por seus interesses.

Numa fria manhã do ano de 1990, os catadores de papel da região central da cidade se depararam com um grande contingente policial militar que os acordaram no local onde guardavam seu material com uma ordem a ser cumprida: "remover todos os catadores e suas ferramentas de trabalho" que estavam num casarão abandonado do centro da cidade. O casarão de 18 cômodos na Avenida Barbacena estava penhorado na Caixa Econômica Federal e havia sido vendido em leilão. Segundo Maria das Graças Marçal, conhecida como "Geralda", trabalhando desde 1961 como catadora de papel, líder do grupo durante o episódio e hoje uma das pessoas da coordenação geral da ASMARE,

“quando abri a janela a tropa policial já estava pronta para nos tirar do casarão um sargento me chamou dizendo 'dona Maria a senhora que é a presidente ai desse pessoal todo, a gente veio aqui para tirar vocês todos daí', eu respondi que não podia ser assim e pedi dez minutos, foi nesse tempo que telefonei para a irmã Cristina na Pastoral, ela era o nosso socorro e qualquer problema já nos acostumamos a chamá-la".

Chegando ao local, os membros da Pastoral entraram em contato com a Caixa Econômica Federal e conseguiram uma autorização para que o despejo fosse suspenso. Em seguida negociou-se um prazo para a entrega do imóvel, pleiteando uma indenização para os catadores que ocupavam o imóvel há mais de 10 anos.

A Caixa Econômica concordou em indenizar o grupo que há anos ocupava aquele imóvel. Dona Maria das Graças ficou responsável pela divisão do valor a ser recebido entre os catadores. Isto não criou problemas, pois o valor pago era pequeno e alguns catadores beneficiados aproveitara o que receberam para viajar de volta para as suas cidades de origem. Segundo ela, o problema maior passou a ser, 
"o que fazer com material que estava sendo recolhido pelos companheiros, já que a prefeitura não permitia mais que guardasse o material em qualquer canto"

Nesse mesmo período um terreno de propriedade da Rede Ferroviária Federal, localizado na Avenida do Contorno no bairro do Barreiro, foi ocupado por um outro grupo de catadores de papel e suas famílias. Estes, ao serem orientados pela Pastoral da Moradia resolveram fazer do local um ponto de aglutinação onde surge a futura sede da Associação.

No início, o local passou a funcionar precariamente, devido à ausência de infra-estrutura para depositar os materiais recicláveis. Para zelar pela segurança do material recolhido, os catadores improvisaram barracas de lona para passar a noite e com o passar do tempo o local se deteriorou.

Em $1^{\circ}$ de maio de 1990 foi fundada oficialmente a ASMARE. No início a rua era a sede da entidade e também o seu ponto de encontro, e à medida em que se ocupou o espaço na Avenida do Contorno o local passa a representar mais um ponto de integração. Os catadores elegeu uma coordenação para direcionar as atividades da Associação. Segundo José Aparecido"foi necessário todo um trabalho para convencer, as famílias e os catadores, que aquele local recentemente ocupado seria para garantir o trabalho deles, não poderia servir como moradia senão desvirtuaria o objetivo e perderia credibilidade junto à população, o local estava se transformando num grande lixão e numa favela".

Convencidos pelos membros da Pastoral, os catadores passaram a utilizar o terreno como local de trabalho e organizaram, com o apoio da Pastoral de Rua, ocupações em áreas abandonadas nas adjacências, que serviram para construir suas moradias. José Aparecido narra que muitos catadores já conseguiram a posse definitiva dos terrenos ocupados e que até hoje residem nas proximidades da sede da avenida do Contorno em função das ocupações organizadas naquele período.

O passo seguinte foi o de conseguir a doação do terreno onde já funcionava a sede ASMARE. Isto seria objeto de uma negociação entre a Prefeitura e a Rede Ferroviária Federal. As melhorias e a construção de uma infra-estrutura necessária para consolidar a Associação só poderiam ser feitas com a obtenção de garantias legais da posse do terreno. A legalização do terreno foi conseguida após muitas mobilizações realizadas para pressionar a Prefeitura a resolver a questão.

Conseguidas as garantias necessárias para permanecer no local, o grupo de catadores e a Pastoral da Moradia passaram a se preocupar em construir no imóvel as instalações 
adequadas para dispor o material que era trazido diariamente pelos catadores. A saída foi tentar junto ao Poder Público que este colaborasse na construção do galpão.

O Poder Público resistia à idéia dando a justificativa que seu papel já havia se esgotado na negociação da posse do imóvel. Novamente foram necessárias mobilizações e muita pressão em conjunto com os setores organizados da sociedade com o objetivo de sensibilizar o prefeito. Em setembro de 1992, após muitas mobilizações diante da prefeitura, a construção do prédio ficou pronta, entretanto sem a infra-estrutura necessária. Não havia instalações de água e luz, e faltavam também os equipamentos básicos para o funcionamento mínimo da Associação. Segundo José Aparecido Gonçalves,

"foi preciso que os catadores ocupassem o gabinete do prefeito para que se ligasse uma torneira de água e se fizesse a instalação dos demais equipamentos necessários, a única forma de nos atender era fazendo pressão".

Os anos de 1991 e 1992 refletiram um amadurecimento da Associação. Poucas foram as parcerias estabelecidas e os administradores da cidade não tinham ainda, por iniciativa própria, desenvolvido quaisquer ações que contribuíssem para o crescimento da ASMARE. Tudo o que havia ocorrido até então era fruto do trabalho coletivo dos catadores, da Pastoral, de ambientalistas e de representantes da sociedade civil que expressavam sua solidariedade à causa.

O trabalho da ASMARE ganhou maior dimensão a partir do ano de 993 quando toma posse na Prefeitura da cidade, uma coligação liderada pelo Partido dos Trabalhadores denominada de "Frente BH Popular". Essa coligação foi encabeçada pelo então vereador Patrus Ananias, conhecido por suas relações com os movimentos sociais' da cidade e também como relator da Comissão Especial da Câmara Municipal de BH que ficou encarregada de coordenar a elaboração da nova Lei Orgânica do Município nos anos de 1989 e 1990.

O que se verifica é que a partir da posse dos novos gestores do município, em 1993, há também uma significativa mudança nas relações entre Poder Público e organizações da sociedade civil, sobretudo a ASMARE.

A nova gestão municipal é quem criará, através do fornecimento de recursos financeiros e humanos, e de infra-estrutura material, as condições necessárias para que a Associação de Catadores de Papel, Papelão e Material Reaproveitável seja hoje uma instituição de 
visibilidade nacional e que muito tem contribuído para que outras experiências surjam em diversos outros municípios do Brasil.

É necessário destacar o papel do Poder Público e a importância que sua presença representou num cenário onde as dificuldades emergem de situações onde a maioria dos envolvidos estão vivendo em condições subumanas de sobrevivência.

\section{O Poder Público enquanto parceiro e estimulador}

O primeiro passo dado de forma concreta, pelo Poder Público, e que resultou num ambiente favorável à obtenção do capital social, ocorreu em 29 de dezembro de $1992^{15}$, por ocasião da assinatura de um convênio entre a Prefeitura de Belo Horizonte, representada pela SLU - Superintendência de Limpeza Urbana, a Mitra Arquidiocesana; figura jurídica da Igreja Católica que se fazia representar pela Pastoral de Rua, e a ASMARE - Associação dos Catadores de Papel, Papelão e Material Reaproveitável de Belo Horizonte.

O objetivo foi de criar condições de capacitação e de infra-estrutura, para que a Associação dos Catadores pudesse melhorar um trabalho que já estava sendo desempenhado de forma precária e pouco profissional. Neste convênio previa-se também que num futuro próximo, quando a Associação tivesse a sua estrutura consolidada, estaria se transformando numa Cooperativa de Catadores de Papel. ${ }^{16}$

Um outro destaque a ser feito, é que cada uma das partes envolvidas assumiu responsabilidades específicas. Definiram-se papéis específicos e que, conforme veremos adiante, serão fundamentais para que essa experiência fosse bem sucedida.

A Prefeitura, além de criar as condições necessárias para o funcionamento da instituição, com o repasse de recursos financeiros, estabelece um compromisso em "incrementar a coleta seletiva de lixo, conforme dispõe a Lei Orgânica do Município". Isto torna a ASMARE uma parceira central nessa nova iniciativa, a Prefeitura também se encarrega de formular as iniciativas para criar um clima amigável na relação dos catadores com a população.

15 Período de transição entre os governos Eduardo Azeredo do PSDB e de Patrus Ananias do PT, este último tomou posse três dias depois 01.01.93. Por questões legais, o convênio ainda foi celebrado na gestão Eduardo Azeredo.

16 Ver página 01 do texto do Convênio registrado em 29.12.1992 na Procuradoria Geral do Município de Belo Horizonte. 
Além disso, o Poder Público também se comprometia em "dar apoio técnico através da Secretaria de Desenvolvimento Social e da SLU, na sistemática de aproveitamento do papel, papelão e outros materiais recicláveis", e "divulgar para a população da cidade, os trabalhos exercidos pela Associação, objetivando, unicamente, o reconhecimento da importância do serviço executado para a sociedade em geral, salientando as vantagens obtidas nos aspectos econômico e ecológico". ${ }^{17}$

A Mitra Arquidioesana, representada a Pastoral de Rua inicia todo um trabalho de organização junto aos catadores de papel, se "responsabiliza pelo fiel cumprimento de todas as obrigações assumidas pela Associação”. Neste momento, os membros da Igreja assumem oficialmente uma responsabilidade já existente desde o início do contato com os catadores. Agora o trabalho dos agentes da Pastoral terá a função específica de zelar pelo sucesso do convênio, pois serão eles os encarregados acompanhar o andamento de todo o trabalho dos catadores, cuja as obrigações descreveremos a seguir:

A ASMARE assume várias obrigações previstas e que são vitais para a manutenção do convênio e o conseqüente sucesso da experiência. Cabe à entidade cuidar do galpão cedido pelo Poder Público, cadastrar e identificar todos os associados, ampliar a presença da Associação através da criação de núcleos de trabalho em pontos estratégicos da cidade e cuidar do bom andamento de todo o trabalho.

Assim é dado um passo decisivo para que o trabalho dos catadores fosse desenvolvido de forma profissionalizada. A entrada do Poder Público representa um fator de fundamental importância, em virtude do conjunto de obrigações e objetivos assumidos Esta nova fase de relacionamento poder público e catadores de papel revela a emergência de uma nova forma de pensar as questões relativas a População de Rua da cidade.

O fato do Poder Público, além de repassar recursos financeiros, se preocupar com a profissionalização e com a valorização do trabalho dos catadores e se encarregando também de realçar as importâncias econômica e ambiental para a população da cidade através de um trabalho de conscientização pública, demonstra uma sensível mudança de postura face a problemática.

Os membros da Pastoral da Rua atribuem essa mudança de postura do Poder Público à nova concepção política liderada por pessoas que também conheciam e tinham 
cumplicidade com a história de luta dos catadores de papel. Na avaliação de José Aparecido Gonçalves,

“ a entrada de Heliana Katia na direção da SLU viabilizou enquanto Poder Público o desenvolvimento do processo de coleta seletiva prioritariamente com os catadores de papel. Na medida em que isso foi assumido pelo Poder Público, provocou uma qualidade muito maior no trabalho dos catadores, isso porque tecnicamente a gente não tinha as condições de conduzir sozinhos o trabalho".

Na medida em que o Poder Público reconhece os catadores de papel como agentes da limpeza urbana, também assume um novo papel frente aos catadores. Ao invés de perseguir como se fazia nas gestões anteriores, agora a ordem era de somar esforços e de qualificar o trabalho dos catadores tecnicamente.

O termo "qualificar tecnicamente" não significa apenas instrumentalizar os catadores para que consigam um maior grau de produtividade, sabendo identificar quais os materiais recicláveis. Nos princípios presentes na formulação de um curso de capacitação desenvolvido pelo Poder Público, e pelo qual todos os catadores precisam passar o termo "qualificar tecnicamente" refere-se também a um processo de conscientização ecológica onde estes são informados sobre o ganho ambiental para a cidade decorrente do seu trabalho. As palavras de Dona Geralda confirmam essa iniciativa,

"Eu e minha família sabemos quantas árvores o nosso trabalho economiza, esses dias visitamos o aterro e ai soubemos também que muito lixo não foi pra lá devido ao nosso trabalho, o nosso trabalho contribui também para aumentar a vida do aterro e limpar a cidade".

Essa preocupação com a consciência ambiental mostra a existência de um esforço para que os fatores econômicos, que são fundamentais para a sobrevivência dos catadores, não sejam dissociados dos fatores sociais. O trabalho de formação de uma consciência ecológica tem provocado alterações comportamentais. Os envolvidos com a experiência relatam mudanças de hábitos em relação à higiene e limpeza dentro de suas próprias casas. Um fato que também deve ser ressaltado, é que esse comprovado ganho ecológico, tem sido um motivo de orgulho para os catadores. Para além dos aspectos econômicos, estão conscientes de que contribuem para minimizar as alterações no ecossistema. Esse ganho ambiental é um instrumento político que muitos catadores utilizam como argumento ao solicitar aos comerciantes, empresas e moradores a separação dos materiais recicláveis. 
A somatória de esforços representada pela Asmare, pelo Poder Público e pela Igreja Católica, demonstra que ao se criar as condições favoráveis para o desenvolvimento do trabalho de uma população que por muito tempo sofreu todos os tipos de constrangimentos sociais, consegue-se ganhos de cidadania que são de extrema relevância social. Esses ganhos de cidadania estão presentes nos fatos de aprender a resistir a eventuais constrangimentos por intermédio da defesa de seus direitos, de reconhecer a importância de se preservar o meio ambiente como um patrimônio de todos e também pelo fato de se recuperar a auto-estima de cada um dos catadores de papel.

A equipe que assumiu a prefeitura em 1993, e que tem continuidade através do trabalho mantido pela gestão que tomou posse em janeiro de 1997, tem dado seqüência ao processo de amadurecimento da ASMARE e reafirmado o compromisso de continuar criando todas as condições necessárias para que o grau de autonomia da Associação aumente cada vez mais, a ponto desta se tornar auto-sustentável.

Se as gestões anteriores tivessem tido a sensibilidade de formular iniciativas necessárias para o desenvolvimento de um trabalho desta envergadura, ao invés de reprimir o trabalho dos catadores, teriam tido a oportunidade de estar ao lado da história dos que lutam por fazer justiça social.

A mudança de comportamento notada na opinião pública da cidade de Belo Horizonte, demonstra que ao tomar as iniciativas de colaborar e de criar condições favoráveis para a organização dos catadores, os membros da Prefeitura estavam também mostrando que é preciso dar respostas a problemas que muitas vezes a população não interpreta de maneira correta, se perguntados à época sobre que medidas deveriam ser tomadas em relação aos catadores de papel, talvez a população indicasse que eles deveriam ser removidos para longe da cidade, hoje a resposta com certeza será outra.

\section{Como funciona e como está organizada a ASMARE}

A Asmare possui um Estatuto Geral aprovado em assembléia prevendo toda a sua regulamentação quanto à adesão de associados e da forma como a entidade será administrada. De acordo com as normas estatutárias é "ilimitado o número de associados", mas para se associar é preciso obedecer alguns pré-requisitos. Os mais importantes estão presentes nos artigos 7, 8 e 9 do estatuto conforme reprodução textual abaixo, 
artigo 7: Somente poderão ser associadas pessoas físicas que catam papel, papelão, ou materiais reaproveitáveis, necessários a sua sobrevivência.

artigo 8: Não poderão ser associados os donos de depósitos ou firmas intermediárias, ou atravessadores que compram e revendem o papel, papelão ou material reaproveitável.

artigo 9: A formalização do ingresso dos associados na ASMARE, que implicará na adesão aos termos deste estatuto, obedecerá os seguintes critérios: solicitação de filiação através do requerimento feito pelo(a) interessado(a), o que também significa a concordância com a remuneração.

Ao se associar o catador manterá uma contribuição mensal de $R \$ 3,00$. Esta contribuição da direito a utilização de todos os serviços disponibilizados pela ASMARE, entre eles estão o de assessoria jurídica, o fornecimento de material adequado para $\mathrm{o}$ desenvolvimento do trabalho e a participação em qualquer um dos eventos educativos que são oferecidos: alfabetização, curso de capacitação etc. Cabe também a Associação fornecer a cada um dos admitidos uma identidade funcional.

A estrutura administrativa da ASMARE está dividida em seis comissões:

1) educação, cultura e lazer;

2) finanças;

3) imprensa e divulgação;

4) infra-estrutura;

5) saúde;

6) meio ambiente. As comissões são compostas por cinco associados e um coordenador eleitos em assembléia geral. Compete a cada comissão cuidar da execução das atividades sob sua responsabilidade, interagindo com as outras comissões. (ver quadro a seguir). 


\section{ORGANOGRAMA ADMINISTRATIVO DA ASMARE}

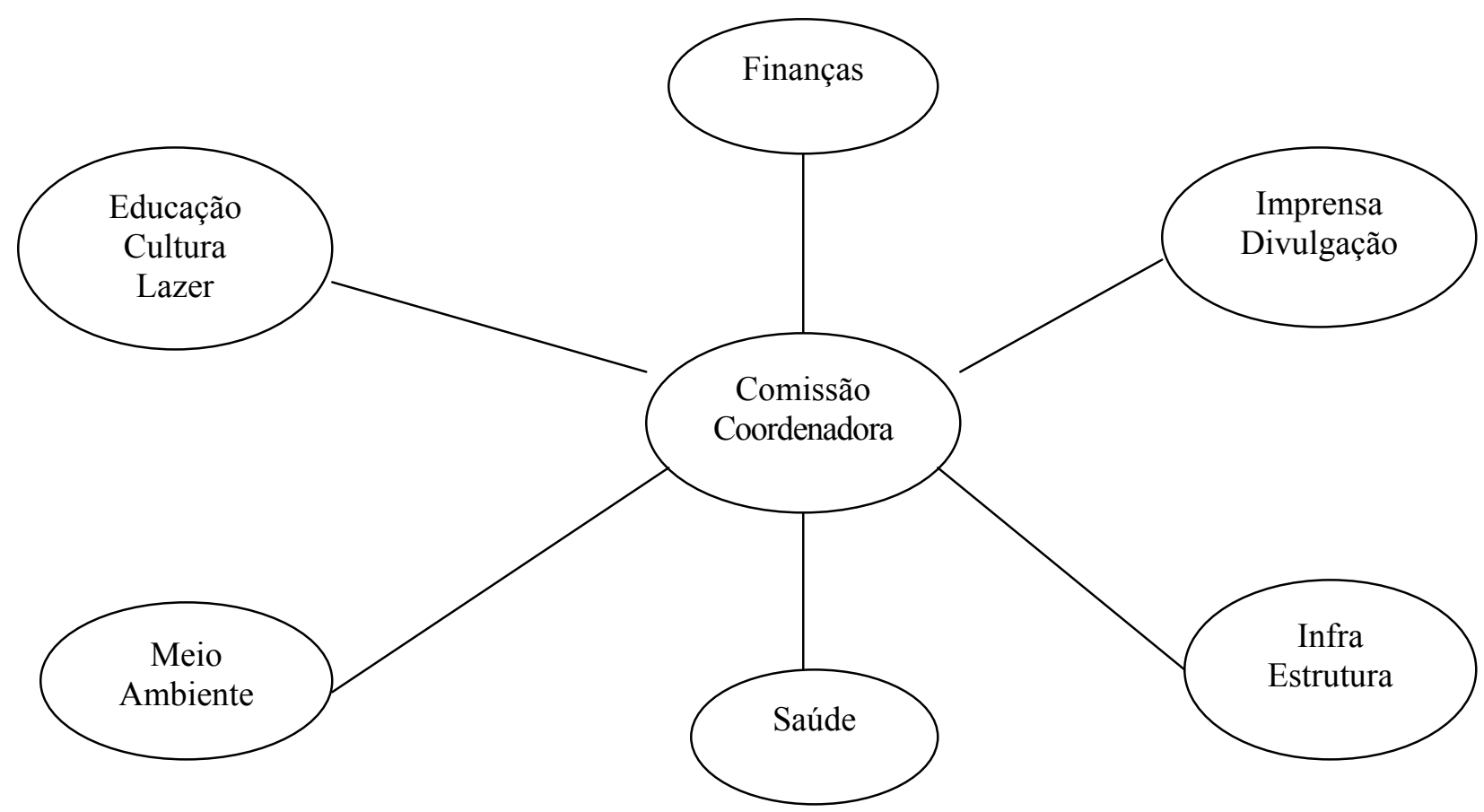

A Comissão Coordenadora está encarregada de articular o trabalho das outras comissões e também de administrar e representar a ASMARE nas mais diversas atividades. Para esta comissão é eleito um animador geral que terá a responsabilidade de representar a ASMARE legalmente, o que em tese representa o papel de um presidente de instituição. Este, junto com o coordenador da comissão de finanças, se responsabilizam oficialmente pela instituição.

O órgão que cuida da fiscalização da gestão da ASMARE é o Conselho Fiscal. Este é composto por três membros eleitos em assembléia para dar parecer sobre a prestação de contas mensal, sobre o balanço financeiro e sobre a execução e previsão orçamentária anual.

Todas essas comissões contam com a assessoria dos agentes da Pastoral de Rua que também exercem o papel de mediadores em eventuais conflitos e, em conjunto com a comissão coordenadora cuida da administração e execução dos trabalhos da ASMARE. 
A comercialização dos produtos é feita pela Associação diretamente com as empresas recicladoras $^{18}$. Para conseguir um melhor preço a ASMARE estoca o material e o vende quando a quantidade se torna um fator de atrativo para os compradores. Não é feita em hipótese nenhuma a venda de material para pessoas que possam ser atravessadores.

A ASMARE tem o controle sobre a produção de cada catador. No fim de cada mês o catador recebe de acordo o seu volume de trabalho. A tabela de preço dos produtos é definida pela própria Associação. Com isso todo o material recolhido pelo catador é comprado pela ASMARE independentemente desta ter ou não vendido o produto. Isto tem garantido um crescente ritmo de trabalho já que não há, por parte dos catadores, a preocupação de recolher e já está vendendo o produto, a venda do produto é feita exclusivamente pela Associação.

A renda média mensal do catador oscila entre dois e seis salários mínimos. Quem produz mais, além de ter melhor remuneração, recebe cestas básicas doadas - um total de dez pela Caixa Econômica Federal como prêmio, e tem também uma maior participação nos resultados que são distribuídos ao final de cada ano como $13^{\circ}$ salário.

A evolução cronológica do desempenho da ASMARE que se faz mais adiante neste relatório tem como objetivo destacar como os catadores de papel têm conseguido consolidar a Associação, e como esse trabalho tem se ampliado para iniciativas que transcendem as questões relacionadas à sobrevivência financeira do grupo.

\section{3 - Consolidando a parceria Asmare, Poder Público e Pastoral de Rua}

Com a definição das diretrizes e dos papeis de cada um dos atores sociais, o próximo passo era o de consolidar a parceria através do resultado de um bom trabalho. Isto se concretiza na medida em que o poder público garantiu através do convênio a utilização do galpão da avenida Contorno pelos 31 catadores associados existentes no início de 1993.

Neste mesmo ano a SLU realiza uma pesquisa que aponta para mais de 500 pessoas, somente na região central da cidade, da coleta de papéis e papelão. Estes estavam fazendo a triagem das mercadorias nas calçadas, e transportando o material em carrinhos de madeira cuja estrutura era bastante precária e sem nenhum tipo de segurança ${ }^{19}$. 
Os resultados da pesquisa mostram que era preciso ampliar o alcance do trabalho desenvolvido, e que para tanto era necessário também a legitimação de uma política pública de coleta seletiva, visando o engajamento de um maior número de catadores, principalmente aqueles que ainda não estavam vinculados à Associação. Assim, a implementação da coleta seletiva se somaria aos roteiros de trabalho dos catadores em suas andanças pelas ruas da cidade.

Para viabilizar a Coleta Seletiva torna-se requisito que o Poder Público inicie a instalação dos LEV's - Locais de Entrega Voluntária -, em vários pontos estratégicos da cidade como: praças, postos de gasolina, associações de moradores, igrejas, etc. Estabeleceu cotas de responsabilidade para o funcionamento adequado dessa nova política, e novamente coube à Pastoral de Rua a função de acompanhar e orientar o desenvolvimento da experiência junto aos catadores. O quadro apresentado a seguir mostra a dinâmica atribuída a cada um dos atores sociais envolvidos na viabilização dessa nova experiência.

\section{RESPONSABILIDADE DOS PARCEIROS NA COLETA SELETIVA}

\begin{tabular}{|c|c|c|}
\hline POPULAÇÃO & PREFEITURA/SLU & ASMARE/PASTORAL DE RUA \\
\hline $\begin{array}{l}\text { SEPARAR OS MATERIAIS } \\
\text { EM CASA }\end{array}$ & $\begin{array}{l}\text { GARANTE O CATADOR COMO } \\
\text { PARCEIRO QUASE } \\
\text { EXCLUSIVO }\end{array}$ & $>\quad$ TRIAGEM EFICIENTE \\
\hline \multirow[t]{6}{*}{$>\quad$ LEVAR ATÉ OS LEV's } & $\begin{array}{l}\text { FABRICA, INSTALA E } \\
\text { MANTÉM OS LEV's }\end{array}$ & $\begin{array}{l}\text { CUIDA E MANTÉM OS } \\
\text { GALPÕES }\end{array}$ \\
\hline & $\begin{array}{l}>\text { EDUCA A POPULAÇÃO PARA } \\
\text { PARTICIPAR }\end{array}$ & $\begin{array}{l}\text { GARANTE O } \\
\text { ARMAZENAMENTO E } \\
\text { COMERCIALIZAÇÃO DO } \\
\text { MATERIAL COM QUALIDADE }\end{array}$ \\
\hline & $\begin{array}{l}>\text { COLETA OS MATERIAIS NOS } \\
\text { LEV',s }\end{array}$ & $>$ ABORDAGEM DE RUA \\
\hline & $\begin{array}{l}\text { CAPACITA OS CATADORES } \\
\text { PARA ATUAREM COMO } \\
\text { PROFISSIONAIS }\end{array}$ & $\begin{array}{l}>\text { ACOMPANHAMENTO SÓCIO- } \\
\text { PEDAGÓGICO }\end{array}$ \\
\hline & $\begin{array}{l}>\text { ALUGA E EQUIPA OS } \\
\text { GALPÕES }\end{array}$ & $>$ FORMAÇÃO DE LIDERANÇAS \\
\hline & $\begin{array}{l}>\text { CONTROLA A COLETA } \\
\text { SELETIVA }\end{array}$ & $\begin{array}{l}>\quad \text { IMPLEMENTAÇÃO DE INFRA- } \\
\text { ESTRUTURA }\end{array}$ \\
\hline
\end{tabular}

O ano de 1993 concretiza o período do amadurecimento da experiência, sendo que a produção média mensal de materiais recicláveis alcança 9 toneladas mês. Nesse mesmo 
ano, a prefeitura em conjunto com a Pastoral de Rua e o CEMPRE - Compromisso Empresarial pela Reciclagem20, monta o primeiro curso de capacitação dos catadores. A previsão para 1994 era de um aumento no volume de retirada de materiais recicláveis e também de um acréscimo no número de associados da ASMARE.

A população começava a ver o trabalho dos catadores de uma forma diferente na medida em que circulam pela cidade devidamente uniformizados e com um cuidado maior com a higiene pessoal. Os catadores começaram a solicitar diretamente a população, que esta proceda a separação do material reciclável.

\section{4 - Amplia-se a experiência}

Em 1994 o número de associados aumenta para 156. Recolhe-se uma média mensal de 34,5 toneladas de materiais recicláveis. O curso de capacitação realizado pela SLU em parceria com o CEMPRE - Compromisso Empresarial pela Reciclagem e com a Pastoral da Rua, tem continuidade representando um espaço de aprendizado importante para os catadores. Estes adquirem novos conhecimentos sobre o manuseio e o acondicionamento adequado do material, assim como uma melhor compreensão a respeito da lógica de funcionamento do mercado.

O curso de capacitação se preocupa também em formar nos catadores uma consciência ambiental, informando-os sobre os benefícios que as suas atividades trazem para o meio ambiente da cidade, e coloca-os frente à necessidade de desenvolver novos padrões de comportamento ambiental.

Uma das causas que possibilitou esse significativo incremento no número de associados da ASMARE, foi o fato de o Poder Público ter cumprido com mais um de seus compromissos. Aluga um segundo galpão de triagem, com $3200 \mathrm{~m}^{2}$ na Rua Curitiba na região central da cidade, retira vários pontos críticos de concentração dos catadores em ruas e praças da zona comercial.

Esse novo espaço de trabalho proporcionou uma significativa mudança nas condições de trabalho dos catadores, na medida em que estes são retirados das vias públicas onde faziam a separavam e organizavam o material recolhido. $\mathrm{O}$ fato muitos eles de ainda estarem trabalhando em vias públicas estigmatiza, e os responsabilizava pela sujeira nas ruas. $\mathrm{O}$

20 Associação de Empresas sem fins lucrativos que visa promover a reciclagem dentro de uma visão do gerenciamento integrado de resíduos sólidos. Faz parte da Associação as seguintes empresas: Brahma, Coca-Cola, Enterpa, Gessy Lever, Nestlé, Pepsi-Cola, Procter \& Gamble, Rhodia-ster, Souza Cruz, Suzano, Tetra Park e Veja Sopave. 
dirigente da ASMARE, Valdencir Rodrigues da Silva, que há mais de 10 anos vive da separação de materiais recicláveis nas ruas diz que:

“o local será muito importante, pois evitará que continuemos separando o lixo nas ruas, facilitando também a comercialização do papel. Queremos colocar aqui uma balança e uma prensa para preparar o material antes da venda". ${ }^{21}$

A declaração dada pelo catador e líder da ASMARE, Valdencir Rodrigues Silva, mostra claramente o significado que o novo galpão terá no desenvolvimento das atividades profissionais no cotidiano dos catadores. Revela também uma significativa preocupação com a profissionalização do trabalho, o que pode ser atribuído ao curso de capacitação.

Com o avanço do trabalho de parceria, a imagem do Poder Público e dos catadores de papel perante a população se modifica. Os catadores não mais são vistos como "população de rua" e sim como um grupo de pessoas que desenvolve uma atividade profissional digna de todo o respeito. O Poder Público rompe com uma imagem caracterizada pela repressão e pela inoperância face ao problema, passando não só a obter legitimidade pelo trabalho, como também a receber muito apoio da população. Assim vários setores da sociedade mais organizada de $\mathrm{BH}$ começam a se comprometer com a coleta seletiva não só pelo seu apelo ecológico, mas também pelo conteúdo social que esta iniciativa representa.

A produção individual dos catadores aumentou significativamente após implantada a coleta seletiva, a perspectiva é de um aumento do volume de trabalho, o que cria a possibilidade de oferecer oportunidades aos demais catadores, que ainda não estão incorporados a Associação.

A igreja, por seu lado, também desenvolve várias iniciativas de apoio dentro das paróquias da cidade. A Arquidiocese solicita que em cada uma das paróquias, os padres orientem os seus fiéis a separarem o seu lixo doméstico destinado-o aos catadores.

\section{5 - A produção dobra e os catadores se tornam um exemplo para a cidade}

O ano de 1995 é marcado por investimentos na melhoria da infra-estrutura operacional e administrativa da Asmare com o objetivo de se garantir condições de trabalho mais adequada. Monta-se um escritório para o setor de controle administrativo: entrada; compra e venda de materiais recicláveis, compras em geral, bem como um local de pagamentos

21 Ver reportagem "SLU inaugura galpão para catadores de papel” publicada no jornal O Estado de Minas em 27 de junho de 1994. 
gerais na sede da avenida do Contorno. São instalados boxes e divisórias nos dois galpões existentes, com o objetivo de melhor agilizar o trabalho operacional de triagem dos materiais trazidos pelos catadores.

Nesse ano, através de um projeto financiado pela ONU - projeto LIFE, também é criada a oficina de formação profisssional de adolescentes direcionada aos filhos dos catadores. A opção é pela formação de jovens marceneiros dentro de uma marcenaria-escola criada no galpão da Avenida do Contorno.

Nesta marcenaria são fabricados os diversos equipamentos de consumo da própria Asmare; dentre eles os carrinhos utilizados pelos catadores de papel para a retirada de materiais recicláveis das ruas, cabos de vassouras etc.

\section{A ASMARE ganha maior dimensão}

Com a consolidação do trabalho da Asmare uma outra preocupação se coloca para os atores sociais envolvidos, a criação de atividades que fortaleçam os laços sociais entre os catadores e também consolide a imagem positiva que estava sendo conquistada junto á população.

A primeira iniciativa ocorre em fevereiro de 1995 durante o desfile de carnaval da cidade. Os catadores de papel, com o apoio da SLU e da Pastoral de Rua, se organizam como uma escola de samba e são incluídos no desfile oficial da cidade. Para concretizar esta atividade cultural somam-se aos esforços dos catadores de papel, os estagiários da SLL e da Secretaria Municipal de Cultura. O enredo escolhido foi "Cidadania, direito de todos", onde segundo Carla Alves, ${ }^{22}$

“é retratada a história e os problemas enfrentados por eles e também suas reivindicações, com serenidade, leveza e bom humor". 23

Sob a denominação de "Escola de Samba dos Catadores de Papel" cerca de 360 pessoas entre catadores e familiares, simpatizantes e pessoas envolvidas com o trabalho da Asmare, se dividiram em oito alas: saúde, educação, habitação, alimentação, trabalho, bateria, comissão de frente e ala dos amigos do povo de rua. Todas as fantasias foram confeccionadas com material reciclável resultado do próprio trabalho dos catadores. 
O processo desencadeado através das atividades culturais, além de proporcionar atividades de lazer aos catadores, também teve o mérito de servir simultaneamente como uma prática de educação ambiental. Segundo Carla Alves,

“com a confecção das fantasias, eles estão vendo pela primeira vez, os materiais por eles recolhidos ganharem uma importância". ${ }^{24}$

Os resultados obtidos em 1995 apontam para 183 associados. A produção média mensal de materiais recicláveis praticamente dobra em relação ao ano anterior, representando um volume próximo de 60 toneladas ${ }^{25}$. Estes resultados são comemorados pela ASMARE com um almoço de Natal, "um encontro de confraternização com espírito natalino" que contou com a presença de todos os catadores associados e de seus familiares. São distribuídos prêmios em dinheiro equivalentes à produtividade mensal de cada catador. Segundo Maria Cristina Bove da Pastoral de Rua, cada catador recebeu entre $\mathrm{R} \$ 100,00$ e $\mathrm{R} \$ 1.000,00$, referentes à participação nos resultados alcançados pela ASMARE.

Também são contemplados, com prêmios durante o almoço natalino, dois dentre os 20 alunos pioneiros da oficina de marcenaria porque não faltaram em sequer um dia de atividade. Foram premiados com caixas de ferramentas e, orgulhosos, viram os carrinhos e outros materiais que produzem expostos no galpão durante a festa de confraternização.

O evento serviu também para inaugurar as novas instalações do galpão da avenida Contorno oferecendo uma nova infra-estrutura de cozinha, sanitários e chuveiros. Segundo Maria Cristina Bove, da Pastoral de Rua,

"a preocupação com a construção dos novos chuveiros e sanitários foi a de criar dependências infantis para que as crianças adquiram novos hábitos de higiene ${ }^{, 26}$

O ano de 1995 marca o período em que a ASMARE passa a ter uma atuação mais ampliada, voltando-se para a valorização do catador de papel enquanto ser humano inserido numa sociedade cada vez mais complexa e exigente nas suas demandas sociais.

As iniciativas tomadas em relação a criação de uma escola-marcenaria, a distribuição de uma premiação extra aos catadores que mais produziram, o investimento em infra-estrutura de trabalho e a preocupação em consolidar o tecido social em formação, são resultados do grau de organização que atingiu o trabalho da Associação, o que era antes pensado como a

25 Ver "A Coleta Seletiva de BH e sua articulação com os Catadores de Papel", in Coleta Seletiva BH Reciclando, SLU, março de 1997. 26 Ver reportagem "Catadores de papel comemoram o Natal", publicada em 22 de dezembro de 1995, página 20 no jornal "O Estado de Minas". 
maneira imediata de organizar uma população marginalizada socialmente, em pouco tempo tem se transformado numa experiência exemplar de resgate de justiça social

O ano de 1996, é marcado pela expectativa de consolidação de um trabalho profissional e da ampliação das iniciativas voltadas para qualificação dos catadores. Isto representa um esforço pela valorização não só da sua atividade profissional, como também na preparação para que garantam um relacionamento cada vez mais autônomo com a sociedade, recuperando sua auto-estima e orientados sua cidadania plena.

\section{6 - A ASMARE se consolida.}

Os resultados colhidos em 1995 foram tidos como fruto do trabalho coletivo dos catadores, da Pastoral de Rua e da Prefeitura através da SLU. As expectativas para 1990 são maiores vislumbrando novas iniciativas de parceria e a possibilidade de alcançar um grau de autonomia cada vez maior. Os catadores que antes eram reticentes em se aproximar da população, agora não só convencem a população sobre a importância da separação dos materiais, como estabelecem diretamente com os comerciantes um horário para recolher o material reciclável no final do expediente. O horário de "panha" como é traduzida a palavra "recolhimento" pelos catadores se inicia após as 16:30 horas.

Essa mudança de postura pode ser observada pelos resultados alcançados no ano de 1996, e pelas novas iniciativas do Poder Público que contribuem significativamente para que a Associação ganhe uma dinâmica participativa cada vez maior.

Uma dessas iniciativas foi a criação de uma bolsa-escola no valor de um salário mínimo para as famílias que tenha crianças em idade escolar, mantenha-os freqüentando a escola. Além do incentivo financeiro, a ASMARE também tem desenvolvido atividades de reforço escolar dirigido a essas crianças.

Um dos primeiros resultados desse programa foi o aumento do índice de aprovação entre as crianças beneficiadas, além de uma sensível melhora na relação das crianças com as suas famílias. Segundo informações obtidas junto à Pastoral de Rua, essa iniciativa beneficia cerca de dez famílias. O número de beneficiados é pequeno porque o programa só atinge as famílias residentes em Belo Horizonte. A maioria dos membros da ASVIARE reside em municípios localizados na Região Metropolitana.

Uma outra iniciativa desencadeada pela parceria SLU, ASMARE e Pastoral Rua, foi a implantação de um projeto de alfabetização de adultos destinado aos catadores. Dos 20 
inscritos, 12 concluíram o primeiro módulo e estão dando continuidade aos estudos. Este trabalho é desenvolvido através da utilização de temas do cotidiano dos catadores como: vida, voto, coleta seletiva e Natal. Segundo os responsáveis por esta iniciativa, "verificouse a necessidade de continuidade, visto que o acesso e o cruzamento desses saberes são condições fundamentais para o avanço da luta pelos direitos e pelo resgate da cidadania". ${ }^{27}$

\section{A ASMARE se expande pela cidade}

Em julho de 1996, dando continuidade ao processo de expansão é inaugurado o terceiro galpão de trabalho para os catadores. Contando com um espaço de $600 \mathrm{~m}^{2}$ e localizado na Rua Itambé, bairro Floresta, próximo da região central da cidade abriga 25 catadores que ainda utilizavam da avenida dos Andradas. A medida foi recebida com satisfação pelos usuários da avenida; incluindo comerciantes e pedestres.

O novo galpão compensava uma longa espera na medida em que há mais de três anos eles já aguardavam essa medida. Os catadores afirmam que com esse novo galpão se evitará o estrago de no período de chuva. Outros apontam para a importância de se conquistar um local para fazer a triagem e o armazenamento do material, e isto permite mais tempo para se dedicar aos filhos e as famílias. Esse argumento é reforçado por Maria Cristina Bove, da Pastoral de Rua, para quem,

"muitos deles tem onde morar, com o galpão eles não vão mais precisar dormir na rua, porque o material vai ficar guardado com segurança”,28

A oferta de mais um galpão somado ao esforço pela formação profissional dos catadores, além da implementação definitiva da coleta seletiva e de um crescente apoio da população, são fatores que justificam o crescimento da ASMARE, tanto no número de associados, quanto na produção de recicláveis.

Em relação ao número de associados, o ano de 1996 se encerra com quase 200. Já a produção de recicláveis praticamente triplica, atingindo uma média mensal de mais de 160 toneladas $^{29}$, o que representa um crescimento muito significativo se comparado aos anos anteriores.

O ano seguinte é aguardado sob a expectativa de continuidade de um trabalho cada vez mais voltado para a formação do cidadão e para a ampliação do número de beneficiados. O crescimento da ASMARE mostra que a existência de um poder público com um perfil

27 Ver "Relatório de Atividades 1996", ASMARE, 1996.

28 Ver reportagem "SLU retira catadores de papel da Andradas" publicada no jornal Minas Hoje em Dia em 16 de julho de 1997.

29 Ver "A Coleta Seletiva de BH e sua articulação com os Catadores de Papel”, in Coleta Seletiva, BH Reciclando, SLU, março de 1997. 
marcadamente preocupado com questões sociais pode impulsionar iniciativas que, embora de baixo custo, revelam extremamente importantes para amenizar processo de exclusão social.

O ano de 1997 aponta para um sensível crescimento no volume de coleta e produção dos materiais recicláveis e também no número de catadores que se associam. No mês de janeiro são retirados das ruas e destinados para triagem nos três galpões existentes cerca de 212 toneladas de materiais, representando cerca de 30\% acima da média mensal do ano de 1996. A triagem dos recicláveis se distribuiu da seguinte forma. 134 toneladas no galpão da Rua Curitiba; 15 no galpão da Rua Itambé e 94 no galpão da avenida do Contorno.

Esse incremento significativo no volume de coleta dos recicláveis é explicado pelo fato de tradicionalmente haver um aumento no consumo devido às festas natalinas e de fim de ano.

No mês de fevereiro observa-se que o volume de recicláveis destinados aos galpões da Asmare fica em 177 toneladas, 80\% acima da que foi recolhido em fevereiro de 1996, e quase $10 \%$ acima da média desse mesmo ano30. O número de associados aumenta para 210 e vários não-associados passam pelo curso de capacitação, o que é um pré-requisito básico para se filiar à Asmare.

Os materiais recicláveis destinados aos galpões tem duas fontes de origem: 1) os roteiros feitos pelos próprios catadores onde se retira o material pelas ruas da cidade, e 2) os materiais da Coleta Seletiva que são destinados espontaneamente pela população aos Locais de Entrega Voluntária.

O material recolhido pelos próprios catadores em seu roteiro de trabalho representa mais de $90 \%$ do total. Em janeiro de 1997, de um total de 243 toneladas; 220 foram recolhidas nas ruas pelos catadores, e em fevereiro; de um total de quase 177 toneladas, o número recolhido pelos catadores alcançou 159 tons.

Os catadores trabalham basicamente com três tipos de materiais: papel/papelão, plástico e metal. O papel/papelão corresponde a quase $90 \%$, o plástico $7 \%$ e metal e outros materiais $3 \%$.

Os catadores não recolhem materiais de vidro pelo fato desses serem destinados á geração de renda para o Hospital Mário Pena, a conhecida Santa Casa de Misericórdia Isto é fruto de acordo entre a SLU, a Santa Casa e a ASMARE. A contrapartida negociada é que a Santa Casa e a ASMARE estão implantando um plano de saúde para beneficiar exclusivamente os catadores e seus familiares. 


\section{A captação de recursos e as despesas realizadas em 1996}

O demonstrativo financeiro realizado pela Asmare aponta para uma receita de $\mathrm{R} \$ 402.678 .01$ referente ao ano de 1996. Além do repasse feito pela Prefeitura, a entidade tem recebe doações da Cáritas ${ }^{31}$ e também alguns auxílios de terceiros que são solidários a causa. O quadro demonstrativo descreve a importância de cada uma das fontes de receitas na composição final do orçamento da Asmare.

\section{DEMOSTRATIVO DE ORIGEM DAS RECEITAS DA ASMARE NO ANO DE 1996}

\begin{tabular}{|l|c|c|}
\hline \multicolumn{1}{|c|}{ Origem } & Valor em R\$ & Peso em \% \\
\hline Convênio com a Prefeitura & $159.198,00$ & $39,50 \%$ \\
\hline Vendas de materiais & $197.180,05$ & $49,00 \%$ \\
\hline Repasse Cáritas/projeto LIFE & $27.277,10$ & $6,70 \%$ \\
\hline $\begin{array}{l}\text { Repasse Cáritas para equipar a } \\
\text { marcenaria }\end{array}$ & $2.850,00$ & $0,70 \%$ \\
\hline $\begin{array}{l}\text { Doações de terceiros e outras } \\
\text { receitas }\end{array}$ & $15.021,26$ & $3,80 \%$ \\
\hline Mensalidades dos associados & $1.151,60$ & $0,30 \%$ \\
\hline \multicolumn{1}{|c|}{ TOTAL GERAL } & $\mathbf{4 0 2 . 6 7 8 , 0 1}$ & $\mathbf{1 0 0 \%}$ \\
\hline
\end{tabular}

Fonte: Setor Administrativo da ASMARE.

Em relação às despesas, o valor do repasse previsto no convênio com a Prefeitura é totalmente destinado para o pagamento da mão-de-obra e dos encargos sociais dos 25 funcionários divididos entre o setor administrativo, operadores de máquinas e os agentes da Pastoral que são os encarregados de fazer todo o acompanhamento do trabalho desenvolvido. Esse recurso cobre também o valor dos aluguéis e despesas com manutenção dos três galpões.

A remuneração dos catadores é coberta com a receita originada da venda dos materiais. A manutenção da marcenaria e a ajuda de custo que é a dada aos adolescentes que participam do curso de profissionalização são feitas por recursos repassados pela Cáritas através de convênio com o projeto Life da ONU. (ver quadro abaixo):

DEMOSTRATIVO DAS DESPESAS DA ASMARE EM 1996

\begin{tabular}{|c|c|}
\hline \multicolumn{1}{|c|}{ Descrição } & Valor em RS \\
\hline Despesas gerais & $212.527,34$ \\
\hline Pagamento aos catadores & $179.955,54$ \\
\hline TOTAL GERAL & $392.482,88$ \\
\hline
\end{tabular}

Fonte: Setor Administrativo da ASMARE 
Nos valores apresentados já estão incluídos $\mathrm{R} \$ 24.000,00$ que foram repassados aos catadores em dezembro de 1996, como premiação relativa aos resultados obtidos pela ASMARE durante o ano. A expectativa dos envolvidos na Associação, é que esta ganhe um grau de autonomia cada vez maior, reduzindo o peso do repasse do Poder Público na composição geral de sua receita.

\section{A ASMARE na voz dos Catadores e do Poder Público}

A realização de uma experiência com o significado da ASMARE envolve desde o seu início vários atores sociais: catadores de papel, Pastoral de Rua, Igreja, ambientalistas, movimentos sociais e organizações comunitárias. Posteriormente, varias pessoas que formam os citados atores sociais tornaram-se Poder Público, o que possibilitou um nível de intervenção diferenciada daquela que até então exerciam.

O contexto envolvendo o processo de construção da ASMARE, bem como o impacto que esta experiência representa para os atores centrais no processo - Poder Público e Catadores de Papel - são destacados adiante na voz das pessoas que viveram esta história de conquistas que é contada com muita angústia e também com muita alegria por quem viveu todo o processo de amadurecimento da entidade.

$\mathrm{Na}$ voz do poder público veremos o grau de envolvimento que este ator social em com o projeto, seus objetivos e como se relaciona com a Associação, além de tentarmos também verificar o que a administração municipal vislumbra num período de curto e médio prazo com a ASMARE.

Na voz dos catadores verificaremos o significado da Associação em suas vidas, o processo de construção da entidade; a importância que atribuem e como se relacionam. Os depoimentos são cercados de um lado por uma "anti-nostalgia" ao se referir a um tempo, anterior a ASMARE, que não desejam reviver, e por outro, por um grande contentamento ao lidar com o presente, o tempo em que estão convivendo com a existência da Associação, fazendo questão de fazer "justiça" ao se referirem a cada uma das pessoas que estiveram ao lado deles desde os momentos mais difíceis.

\section{A Asmare na voz dos catadores}

A lembrança que se tem é, sempre, a de um período bastante adverso, o período das fugas e do sofrimento com as operações limpeza, a época em que se tinha que dormir na rua para 
que a mercadoria recolhida não fosse saqueada ou danificada pelos próprios companheiros, ou que, uma chuva que caísse de surpresa não estragasse todo o material. Motivos para comparar o que eram suas vidas e até aonde se chegou após o processo de organização da Asmare são os fatos mais recorrentes em suas memórias. Lembranças sempre presentes ao comentar o nome de cada uma das pessoas que contribuíram para que se chegasse ao estágio onde hoje se encontram.

Alguns membros não conseguem traduzir, corretamente, em palavras o significado que a Asmare tem em suas vidas. Enquanto uns choram ao lembrar do passado, outros relatam com uma feição misturada por uma certa angústia vivida num período recente e pela esperança que essa experiência que tem vivido, além de não se acabar possa vir a beneficiar mais pessoas ou como dizem que "mais companheiros venham trabalhar com nós". As palavras de Murilo Sebastião Conceição, adolescente, aprendiz de marceneiro e catador de papel associado da ASMARE há mais de 3 anos revela as angustias vivida num passado recente dizendo que,

"estar na Asmare é um grande prazer, pois eles tiraram nós da rua, da humilhação que nós passávamos, dos policiais que mau tratava a gente, eles fizeram coisas bem interessantes pra gente, dava sopa na rua e ensinava coisas que a gente não sabia. Tudo mudou na minha vida, hoje eu tenho um trabalho e prendi trabalhar em marcenaria e hoje tenho também um pouco de diversão"

Nos relatos observa-se que os catadores de papel, principalmente as mulheres, mantém um espírito de solidariedade que existia desde o período em que apenas a rua era referência das suas vidas. A associada e diretora da comissão de meio-ambiente, Silvia da Paixão Silva apontou para um outro adolescente da equipe de marcenaria da ASMARE, Mauro Celso Fernandes Dias, e relatou a história do adolescente lembrando que,

"de que foi Dona Tereza, uma papeleira-catadora de papel, que trouxe o Mauro pequenininho para junto dos catadores logo no início da Associação. Ele foi abandonado pela família, ficava na rua sem ninguém pra ajudar ele. Hoje ele tem uma profissão por causa do que está aprendendo na marcenaria e está conseguindo muita coisa graças a Associação"

A existência da Associação também é vinculada a melhoria que conseguiram, nos últimos anos, em relação à qualidade de vida. Novamente, o passado recente é referência comparativa para demonstrar o que o aprendizado com a Associação e como sua nova inserção de trabalho tem transformado suas vidas. Silvia Paixão da Silva recorre ao início do processo de organização da entidade para mostrar o salto de qualitativo na sua vida. 
"Nós morávamos nesse espaço, da avenida Contorno, em malocas de lona antes de fazer o galpão. Vinha a polícia tirava todo mundo e depois nós voltávamos Até que um dia surgiu a chegada da Cristina da Pastoral, ai começamos a fazer reuniões com sete ou oito pessoas e a coisa foi indo, nós morando aqui ainda"

"Quando isso virou a Associação foi uma felicidade danada, tínhamos muitas dificuldades, não conseguíamos quase nada. Hoje graças a Deus tudo mudou muito, tenho minha casa que comprei com meu esforço de trabalho e com a ajuda da Cristina da Pastoral que ajudou que a indenização da desocupação saísse, a prefeitura pagou 6 mil reais para cada família que saiu daqui Hoje a polícia não corre mais pra tirar a gente daqui, é tudo muito melhor, aqui e tudo coberto se chover não molha nada. Isso é obra de todos nós, da Pastoral e da SLU, me sinto realizada"

Além dos ganhos econômicos, nota-se também um ganho de consciência ambiental presente no próprio discurso e na atitude dos catadores. Existe uma nova relação com o material com o qual trabalham, isto é resultado do curso de capacitação onde aprenderam a importância de preservar a natureza.

A importância da consciência ambiental é utilizada pelos catadores como argumento para convencer um comerciante ou um morador, sobre a importância de separar o lixo para a reciclagem. $\mathrm{O}$ argumento central é pedagógico e procura demonstrar, entre outras coisas, que a separação de materiais recicláveis contribui para aumentar a vida útil dos aterros, e, no caso do principal produto de trabalho, papel/papelão, a reciclagem ajuda a preservar as árvores da floresta. Esses argumentos se somam ao fato de obter desse trabalho a sua sobrevivência.

As palavras de Anunciação das Dores Paulino de Souza, catadora de papei há mais de dez anos e associada da Asmare desde o seu início, também recorre ao passado para justificar tal mudança de atitude, demonstrando que a existência da Asmare é quem possibilitou essa nova consciência,

"mudou muita coisa, antigamente eu trabalhava onde podia, hoje eu tenho lugar certo para pegar o material, pego no SESC, no SENAC e no comércio, é tudo mais organizado. Estamos ajudando a limpar a cidade, deixando a cidade limpa. Agora me ensinaram a ter cuidado quando vou recolher o material para não prejudicar a minha saúde, e sei que quanto mais eu recolho, mais ajudo a natureza".

A ASMARE no imaginário dos catadores, está relacionada com a sobrevivência e a melhoria da qualidade de vida de suas famílias, e como a entidade vai um dia servir para seus filhos; fazem qualquer coisa para mantê-la. Quanto aos atores sociais que 
contribuíram para que a Associação se tornasse realidade, destacam o papel da Pastoral de Rua, como sendo quem nos momentos mais difíceis sempre estiveram ao seu lado e não permitiu que perdessem a esperança.

O Poder Público é realçado, e os membros da ASMARE não o vêem apenas como o responsável pelo repasse de recursos que tem possibilitado a existência da instituição. Reconhece que a administração Patrus Ananias “onde participa tanta gente que lutou junto com eles", é quem fez todos esforços para mudar uma visão que era estigmatizada na população da cidade, a de atribuir aos catadores a responsabilidade pela existência de sujeira nas ruas.

Os catadores tem consciência que, apesar de todos os esforços existentes, a consolidação da ASMARE dependerá de um maior grau de autonomia em relação poder público. Argumenta-se que uma mudança de governo pode significar também o fím do convênio, dependendo do perfil do novo governo. Atribui-se a prefeitura a contribuição para o resgate da cidadania de uma população que em menos de cinco anos já aprendeu a falar e se colocar de frente aos desafios do cotidiano de uma sociedade que a muito pouco tempo não os reconhecia enquanto cidadãos.

\section{A Asmare na voz do Poder Público}

A Asmare é uma parceira prioritária na execução da coleta seletiva na cidade. Isto não ocorre porque está previsto na Lei Orgânica Municipal, mas pela vontade política da equipe que assumiu a direção da Prefeitura Municipal de Belo Horizonte desde o ano de 1993. Essa afirmação é repetida pelos membros da equipe de trabalho que permanece apesar da mudança de governo ocorrida no início de 1997.

O vínculo da equipe de trabalho com os catadores de papel é anterior ao trabalho na prefeitura. Segundo alguns membros da equipe, o trabalho se inicia com os membros da Pastoral de Rua, quando os catadores ainda eram verdadeiros andarilhos marginalizados por boa parte da sociedade local e pelo próprio Poder Público.

A vitória no processo eleitoral em 1992 trouxe a possibilidade de se concretizar muitas das reinvindicações feitas em conjunto com os catadores num passado recente. A própria indicação da equipe de trabalho que assumiu a SLU, tendo Heliana Kátia Tavares à frente, foi legitimada pelos movimentos sociais, ai incluídos os membros da Pastoral de Moradia que colaborou na fundação da ASMARE. 
Atualmente, após vários anos de gestão onde se reconhece a importância da iniciativa, o poder público verifica que seu papel é de uma importância muito maior do que inicialmente se imaginava. Observa-se que muito mais do que o repasse de recursos, a iniciativa se amplia, estimulando parcerias e viabilizando formas de capacitação que colocam para a população uma nova imagem dos catadores de papel. Segundo Luiz Henrique Hargreaves, atual Superintendente da SLU,

"O trabalho que foi feito representou um ganho significativo. A intenção agora é a de consolidar e ampliar todo o trabalho já existente. Para tanto vamos instalar mais Lev's e estimular os moradores a participarem da coleta seletiva para aumentar ainda mais o volume de materiais recicláveis destinados a Asmare. Estamos capacitando todos os 210 associados a trabalharem da forma mais adequada possível, além disso, esse curso de capacitação tem tido também um enfoque voltado para o relacionamento humano, o que tem permitido aos catadores um grau de informação que os permite convencer um dono de loja, ou um síndico de condomínio, a fazer a separação do material reciclável. Antigamente o catador de papel era um lixo humano, hoje é um parceiro que contribui para melhorar a cidade, é um profissional da limpeza urbana".

Observa-se vontade do poder público em dar continuidade ao processo incentivando experiências com o grau de importância da ASMARE. Diversas iniciativas foram colocadas em prática pelo próprio poder público, como é o caso da formulação e estimulo da coleta seletiva em parceria com os catadores. Com o amadurecimento da experiência, a tendência é que na medida em que o nível de organização da Associação se consolide, esta se capacite cada vez mais para se tornar uma cooperativa, que é um dos seus objetivos desde o inicio.

Iniciativas nesse sentido já vem ocorrendo lentamente, segundo Marco Túlio Edwirges, colaborador enquanto membro do movimento ambientalista no processo de organização da ASMARE e atualmente respondendo pela Assessoria de Mobilização Social da SLU,

"Estamos agora passando o processo de controle operacional da coleta seletiva para a Asmare, antes quem fazia e operacionalizava a coleta seletiva era nós. Agora a própria Asmare já possui infra-estrutura para realizar este serviço e amadurecimento suficiente para gerenciá-lo, o que significa um ganho de autonomia. Nos encarregamos de dar a formação adequada, agora que estão capacitados já podem se responsabilizar por estes serviços. $O$ Poder Público não está se retirando, está apenas cumprindo um papel, e na medida em que for possivel, a Asmare estará assumindo mais funções que ainda não exerce. Não é papel do Poder Público está eternamente repassando recursos e ajudando no gerenciamento da Associação, o que estamos fazendo é criar as condições para que de maneira segura os catadores assuma totalmente o controle da ASMARE. Isto ocorrerá quando a Associação tiver o maior grau de segurança possivel para se transformar numa cooperativa". 
O valor do convênio estabelecido prevê que o Poder Público estará arcando com as despesas estruturais da Associação. Essas despesas que representa um valor em torno de $\mathrm{R} \$ 180.000,00$ por ano, cobrem a manutenção dos galpões com alugueis e o pagamento do pessoal administrativo.

De acordo com informações cedidas pela SLU, a ação dos catadores de papel, na coleta de recicláveis, representa um ganho de cerca de $\mathrm{R} \$ 9.000,00$ por mês para os cofres públicos em economia de recursos que seriam pagos à coleta normal de lixo.

Aplicando um raciocínio econômico, após um ano o Poder Publico terá um retorno - em relação ao capital aplicado na ASMARE - de aproximadamente R $\$ 108.000,00$. E isso deve ser somado ao fato de que o dinheiro aplicado na Associação contribui efetivamente para a diminuição da crise social. Gerando emprego e renda com a retirada de um contingente da população que dormia na rua, possibilitando um retorno social que supera o valor do capital repassado. Isto demonstra que os investimentos feitos em projetos de cidadania são muito mais eficazes do que possam parecer, e que o retorno social e sem dúvida nenhuma o maior capital que se pode colher.

\section{CONCLUSÕES}

Minimizar o impacto da crise social nas médias e grandes cidades tem sido, sem dúvida nenhuma, um dos principais desafios enfrentados pelo Poder Público no âmbito local. A experiência da prefeitura de Belo Horizonte na sua relação com a Asmare é um exemplo de como uma simples iniciativa pautada pelo diálogo e pelo repartição de responsabilidades pode trazer impactos positivos para toda uma sociedade.

O fato do Poder Público estar contribuindo, através de um convênio, com a manutenção e o aluguel dos galpões da Associação é sem dúvida nenhuma algo da mais alta relevância, se pensarmos que sem esse montante de recursos a entidade estaria praticamente impossibilitada de funcionar com tal alcance social.

Para além do repasse de recursos é necessário destacar também que o Poder Público não se limita ao papel do estado provedor. A Prefeitura através das diversas iniciativas da SLU, tem contribuído significativamente com a viabilização de diversas parcerias no sentido de colaborar com a reconstrução da auto-estima do catador de papel; através da aplicação de cursos de capacitação e alfabetização, e também de atividades de lazer. 
O impacto dessas iniciativas tem provocado uma sensível melhoria das condições de vida dos envolvidos, refletindo na formação de um comportamento ambiental diferenciado. Isto tem se manifestado pelo fato dos catadores estarem plenamente conscientes sobre o impacto positivo que suas atividades tem trazido ao meio ambiente da cidade, além dos ganhos econômicos que representam para si.

Todos os entrevistados reconhecem que os ganhos são muito além do aspecto econômico. Isso serve como argumentação para se contrapor aos defensores de um Estado Mínimo, que vêem reservas o investimento de recursos públicos em áreas que no entender dessas pessoas pertencem à esfera privada. No caso da coleta seletiva, a experiência da ASMARE se contrapõe ao discurso de que o setor privado a gerenciaria com maior eficiência. $\mathrm{O}$ alcance social e os avanços que o setor de limpeza atingiu em Belo Horizonte são considerados argumentos irrefutáveis.

Ao se organizarem numa Associação, onde contaram com o apoio fundamental da Igreja Católica através da Pastoral de Rua, os catadores de papel conseguiram articular em torno si uma rede de solidariedade formada por vários membros da sociedade civil, ambientalistas, vereadores com trabalho junto a movimentos sociais, membros de associações comunitárias e de entidades de defesa de direitos humanos.

A consolidação da ASMARE só foi possível na medida em que grande parte desse grupo que é solidário ao processo de organização dos catadores foi conduzido a prefeitura de Belo Horizonte no processo eleitoral do ano de 1992 Faziam parte desse grupo o prefeito eleito, Patrus Ananias; vereador do PT e Heliana Kátia Tavares, ambientalista que assume no início de 1993 o cargo de Superintendente de Limpeza Urbana da cidade.

As condições estavam praticamente criadas e só restava que os compromissos de solidariedade assumidos durante o processo de organização da ASMARE fossem viabilizados através de iniciativas de políticas públicas.

Essa conjugação de fatores que fez surgir um Poder Público sintonizado com as necessidades mais imediatas dos catadores. As pessoas que contribuíram para a formulação de parcerias e de políticas que contribuíram para o crescimento e consolidação da ASMARE, viveram na prática o processo de adversidades e de angústias pelo qual passaram os catadores durante longos anos.

Isto justifica o fato de que foi numa administração com esse perfil que se pôde exercer iniciativas mais ágeis de combate à exclusão social. Uma das primeiras iniciativas da SLU, 
foi de diagnosticar a quantidade de catadores de papel existentes nas ruas da cidade. $\mathrm{O}$ resultado da pesquisa apontou para aproximadamente 500, especificando os pontos de concentração e os roteiros que fazem durante as suas atividades.

Com o resultado dessa pesquisa em mãos, a SLU planejou um conjunto de iniciativas para atacar os problemas mais imediatos, viabilizando galpões para que os catadores pudessem fazer a triagem e guardar com segurança o material recolhido.

O resultado disso é a existência de três galpões distribuídos geograficamente pelos pontos que concentram a maior quantidade de catadores. O número atual de associados é de 210, quase metade de toda a população identificada na pesquisa em 1993. Essa ação significou a retirada de famílias inteiras que viviam dormindo nas ruas, e que hoje tem suas próprias casas, morando com a segurança que um dia pensaram ter perdido.

É também significativo, o fato de o Poder Público formular políticas tendo como preocupação o conjunto dos catadores e suas famílias. Essas políticas tem se traduzido em: 1) programas para estimular a permanência das crianças nas escolas, 2) a preocupação com a profissionalização dos adolescente, 3 ) o estímulo ao investimento na formação ambiental que tem privilegiado a formação de um cidadão preocupado com as futuras gerações.

Foram esse conjunto de iniciativas que provocou duas mudanças significativas que resultaram na nova imagem que a população tem hoje dos catadores. A primeira é que agora os catadores são vistos como profissionais e respeitados no desempenho de suas funções e a própria população contribui participando da coleta seletiva. A outra é bastante significativa, e representa a mudança pela qual passou o Poder Público. Ao reprimir os catadores em outras épocas o Poder Público acabava legitimando a imagem negativa que a população tinha. Com a mudança de postura ocorre uma inversão na relação da população com os catadores, o próprio Poder Público passa uma imagem vinculada com a preocupação de enfrentar o processo de exclusão social.

Estes fatos mostram que quanto mais o Poder Público cria condições favoráveis para a multiplicação de capital social, mais estará contribuindo diretamente para a diminuição do impacto da crise sócio-econômica sobre a população carente, que sempre é a mais afetada. Esta experiência mostra a importância da disponibilidade do Poder Público para interação efetiva com os movimentos sociais, principalmente aqueles que são a voz e a expressão dos setores socialmente mais carentes. No caso de Belo Horizonte é notório que o sucesso 
da ASMARE, num curto prazo de tempo, se deu por algumas razões que esta o localizadas no processo histórico com o qual se desenvolveu a luta dos catadores.

Nesse sentido é importante destacar o compromisso das pessoas envolvidas e sua crença numa causa mesmo nos momentos de dificuldades provocadas pelo preconceito, repressão e incompreensão dos dirigentes do setor público em épocas anteriores. O fato do Poder Público assumir uma vocação social, de entender a problemática dos catadores demonstrando toda a vontade política de colaborar com a construção desse projeto de resgate da cidadania é um estimulante referencial das possibilidades abertas.

É importante ressaltar que ao criar as condições que possibilitaram que os catadores o resgatassem a sua auto-estima, o Poder Público também contribuiu de maneira muito significativa com a sensível diminuição do peso do preconceito existente na relação da população com os catadores. Hoje é muito comum encontrar os catadores falando com orgulho de sua atividade profissional e da melhoria da qualidade de vida que tem alcançado.

Outro ganho que merece ser destacado é para o meio ambiente da cidade. Ao investir em experiências como a da ASMARE, o Poder Público está dando lições de desenvolvimento sustentável de duas maneiras: 1) ao aumentar a vida útil dos aterros sanitários pelo o simples fato do material recolhido está sendo reutilizado, fato que se desdobra também numa economia de elementos da natureza, 2) gera-se renda para um contigente populacional sem poluir ou causar nenhum dano ao meio ambiente, e esta população beneficiada passa a ter melhor condição de vida o que significa também uma melhor relação com o espaço da cidade.

O resultado da experiência aponta ganhos para toda sociedade. A Prefeitura por um lado, pois ameniza a crise social e se torna capacitada a direcionar suas atenções para outros setores, melhorando sua imagem ao contribuir com os que moravam na rua lhes dando melhores condições de vida, enquanto outras gestões os reprimia. Ganha também a população como um todo, já que esta passa a ter uma outra postura em relação ao meio ambiente domiciliar a partir de experiências como a da coleta seletiva e da participação em outros eventos que permitiu uma aproximação com os catadores, e que serviu para romper com uma relação preconceituosa sem nenhum fundamento. 


\section{Pessoas que foram entrevistadas}

Anunciação das Dores Paulino de Souza - Catadora de Papel

Elcio de Faria Nóbrega - Mestre da Marcenaria

Eulália Pereira - Agente da Pastoral de Rua

Itamar Ferreira Ramos - Adolescente Catador e aprendiz-marceneiro

José Aparecido Gonçalves - Coordenador da Pastoral de Rua

Luiz Henrique Hargreaves - Superintendente da SLU

Mara Luisa Motta Alvim - Setor de Coleta Seletiva da SLU

Marcelo Marra - Coordenador Administrativo da Asmare

Marco Túlio Edwirges - Assessor de Mobilização Social da SLU

Maria Brás dos Santos - Catadora de papel e Coordenadora da Asmare

Maria Cristina Bove - Agente da Pastoral de Rua

Marislane Nogueira - Catadora de Papel

Mauro Celso Fernandes - Adolescente Catador e aprendiz-marceneiro

Silvia Paixão da Silva - Catadora de Papel

Sônia Maria Dias - Setor de Coleta Seletiva da SLU 